\title{
Presidents, Pardons, and Prosecutors: Legal Accountability and the Separation of Powers
}

\author{
Peter M. Shane ${ }^{\dagger}$
}

The post-bicentennial period has produced a substantial literature on alleged vices of our national governmental structure. Our historically predominant principle of "checks and balances," which I will also call "checked separation of powers," allegedly renders our legislative and executive authorities incapable of formulating and implementing a coherent policy agenda with anything like the speed or regularity that compelling problems demand. Although some commentators have recommended restructuring the government, chiefly by emulating parliamentary models, ${ }^{1}$ other writers would promote the coherence of government policymaking by accentuating the separation of legislative and executive powers. ${ }^{2}$ After all, the President's capacity to formulate and implement efficiently a consistent government program could be enhanced not only by rendering the President a prime minister, but also by attributing to the President a substantial and constitutionally vested policymaking role beyond Congress's capacity to regulate. Such authority would move the President, albeit within statutory limits, in the direction of the French executive's inherent decree power. ${ }^{3}$

In important respects, both the Reagan and Bush Administrations advocated this latter philosophy, ${ }^{4}$ although, to be sure, it was always advertised as

$\dagger$ Professor of Law, University of lowa. This article benefitted from the insightful probing of the Cornell law faculty, who were kind enough to discuss an earlier draft in a workshop. I am also indebted to Donna R. Miller, Iowa '95, and Martin L. Wissott, Iowa ' 94 , for their skillful research assistance.

1. See, e.g., C. Douglas Dillon, The Challenge of Modem Govemance, in REFORMING AMERICAN

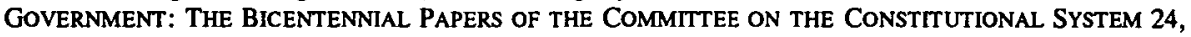
29 (Donald L. Robinson ed., 1985) (arguing that a parliamentary system would afford the government "greater ability to act promptly and energetically in the face of a crisis"); Charles M. Hardin, The Separation of Powers Needs Major Revision, in SEPARATION OF POWERS-DOEs IT STILL WORK? 90, 92 (Robert A. Goldwin \& Art Kaufman eds., 1986) (asserting that replacing separation of powers "with a separation between the government and the opposition" would remedy stalemate); Kevin Phillips, An American Parliament, in REFoRMING AMERICAN GOVERNMENT: THE BICENTENNIAL PAPERS OF THE COMMITTEE ON THE CONSTITUTIONAL SYSTEM, supra, at 191 (claiming that the "counterproductivity of White House and congressional interaction" can be cured by modifying the role of the cabinet). For a thorough analysis and thoughtful rebuttal of the "parliamentary critique," see Thomas $O$. Sargentich, The Limits of the Parliamentary Critique of the Separation of Powers, 34 WM. \& MARY L. REV. 679 (1993).

2. See, e.g., Geoffrey P. Miller, Independent Agencies, 1986 SUP. CT. REV. 41 (1986); Malcolm Richard Wilkey, Judicial Activism, Congressional Abdication, and the Need for Constitutional Reform, 8 HARV. J.L. \& PUB. POL'Y 503 (1985).

3. Article 34 of the French Constitution enumerates those subjects upon which Parliament may legislate through statutes. Article 37 provides that matters not enumerated in Article 34 fall within the exclusive domain of executive regulation. The result is a vesting in the executive of substantial power to regulate domestic affairs through decree. See L. NEVILLE BROWN \& JOHN S. BELl, FrENCH ADMINISTRATIVE LAW 8-13 (4th ed. 1993).

4. I hope to provide a fairly comprehensive account of separation of powers developments under the Reagan and Bush Administrations in another work. In my judgment, the most significant and successful 
of the Administrations' efforts to implement their separation of powers views were the initiatives, discussed briefly infra notes $72-74$ and accompanying text, to intensify presidential oversight of regulatory policymaking. Other episodes revealing these Administrations' separation of powers philosophy include those discussed below, each of which represented a substantial presidential attempt to implement categorical separationist thinking.

The best publicized separation of powers confrontations during the first Reagan Administration were two 1982 executive privilege disputes with Congress. First, Interior Secretary James Watt refused to comply with a congressional committee subpoena for certain documents relevant to the status of Canada under the Mineral Lands Leasing Act. Second, later that year, EPA Administrator Anne Gorsuch became embroiled in a dispute concerning Congress's access to EPA investigative files regarding enforcement of the so-called Superfund Act. The disputes occasioned formal opinions by Attorney General William French Smith claiming that each set of disputed documents was subject to executive privilege, and that a decision regarding whether the executive interest in any such documents' confidentiality outweighed the interest in public disclosure would have to be a decision within the complete discretion of the executive. In the Gorsuch matter, the Justice Department even filed an extraordinary (and unsuccessful) action seeking to prevent the House of Representatives from pursuing a prosecution against Gorsuch for contempt. See United States v. House of Representatives of the United States, 556 F. Supp. 150 (D.D.C. 1983). See generally Peter M. Shane, Legal Disagreement and Negotiation in a Government of Laws: The Case of Executive Privilege Claims Against Congress, 71 MINN. L. REv. 461 (1987) [hereinafter Shane, Legal Disagreement].

Attorney General Edwin Meese later unearthed a relatively new administrative law context in which to assert presidential prerogative. Meese prohibited Justice Department lawyers from entering into consent decrees limiting the future policymaking discretion of administrative agencies. Office of the Attorney General, Department Policy Regarding Consent Decrees and Settlement Agreements (Mar. 13, 1986), reprinted in OfFICE OF LEgal POL'Y, U.S. DEP'T OF JUSTICE, GUIDELINES ON CONSTITUTIONAL LITIGATION 150 (1988). Such decrees had previously been used to settle several lawsuits challenging alleged agency refusals to implement mandatory programs of administrative regulation. Although neither the Attorney General's memorandum containing his order nor a companion press release was entirely clear in explaining the order's rationale, the Attorney General's reasoning was quite apparent. The press release said that the order was a "significant expression[] of our view of the Constitution," intended "to preserve the constitutional prerogatives of the President and other officers of the Executive Branch, including preserving their policy-making discretion." Office of Legal Counsel, U.S. Dep't of Justice, Press Release (Mar. 21, 1986) (on file with the Yale Law \& Policy Review). In context, it was apparently the Attorney General's view that the President has unreviewable and constitutionally vested discretion to determine the regulatory agenda of every administrative agency, and that consent decrees authorizing courts to oversee an agency's agenda in any respect intrude impermissibly on the President's constitutional powers. See generally Peter M. Shane, Federal Policy Making by Consent Decree: An Analysis of Agency and Judicial Discretion, 1987 U. CHI. Legal F. 241.

President Bush's lawyers persisted, in yet other contexts, in asserting a plenary managerial role for the President in supervising all aspects of government administration. In one remarkable case, the Justice Department defended, partly on constitutional grounds, ex parte contacts between the White House and members of an administrative agency conducting a formal on-the-record proceeding under the Endangered Species Act. The Department argued "that including the President and his staff within the [Administrative Procedure Act \& 7, 5 U.S.C. $\$ 557$ (d)(1) (1993)]'s ex parte communication ban would represent Congressional interference with the President's constitutional duty to provide such supervision and guidance to inferior officials." Portland Audubon Society v. Endangered Species Comm., 984 F.2d 1534, 1546 (9th Cir. 1993). Applying the very balancing analysis that is anathema to strict separationists, a Ninth Circuit panel "reject[ed] this argument out of hand." Id.

The Bush Administration's final salvo in the separation wars was an equally unprecedented imbroglio with the Board of Governors of the U.S. Postal Service. In brief, the Board of Governors, an "independent establishment" in the executive branch, sought to challenge certain recommended rate-setting decisions by another such establishment, the Postal Rate Commission. Congress has required that the Justice Department shall provide legal representation for the Board of Governors, except that the Department may also consent to litigation conducted by private attorneys or otherwise independently of the Department. Upon request for representation in these particular matters, the Justice Department not only declined to represent the Board or to consent to independent litigation, but questioned the justiciability of a suit by the Board against another federal agency. When the Board proceeded to file a brief on its own with the U.S. Court of Appeals, the Justice Department asked the Board to withdraw its brief. President Bush ordered the Board to comply with the Department's request, and when the Board demurred, threatened to remove a majority of the Board from office. See Mail Order Ass'n of America v. U.S. Postal Service, 986 F.2d 509, 510-12 (D.C. Cir. 1993).

No comprehensive limitation of the President's administrative powers with respect to the Postal Service 
a proper interpretation of the existing Constitution, not as a suggestion for change. Promoting "categorical separationism," both Administrations asserted that, with a few explicit exceptions, our Constitution contemplates a stark compartmentalization of government powers as legislative, executive, or judicial. Once a power is found to be executive, neither Congress nor the judiciary may limit it. The great virtue of this conception of executive authority under the separation of powers is supposed to be a resulting enhancement of political accountability. ${ }^{5}$

In contrast to the parliamentary critique of our checked separation of powers, the theory of categorical separation has not recently received the sort of thorough analysis and critical assessment that it warrants as a discrete school of constitutional thought. This is worrisome because, unlike parliamentary-style changes, a good deal might be done to implement a categorical separationist vision without the type of formal action that is likely to provoke popular debate or even awareness. Public engagement in abstract issues of government structure and process is, in ordinary times, presumably limited. A President who successfully embeds a categorical separationist program in a sufficiently popular policy agenda may be able to weaken checks and balances substantially without any exposure to widespread public deliberation. ${ }^{6}$ This is so, even

resulted from the ensuing litigation. The President insisted that his authority to remove uncooperative Board members fell within his authority as "Chief Executive" and his charge "to take care that the laws be faithfully executed." Mackie v. Bush, 809 F. Supp. 144, 145 (D.D.C. 1993). The U.S. District Court for the District of Columbia, however, granted the threatened Board members a preliminary injunction prohibiting their discharge pending further orders of the Court of Appeals. The court determined that its authority to enjoin the President, itself a remarkable move, resulted from its inherent power to preserve the appellate court's jurisdiction. Id. at 146-47. The Court of Appeals subsequently held that the Board of Governors did enjoy litigating authority independent of the Justice Department and, thus, the filing of its brief was lawful. Mail Order Ass'n of America, 986 F.2d at 516-23. Neither court determined, however, whether the President could have properly discharged Board members if their filing had been unlawful, or-even if the filing was proper-whether a discharge for insubordination would be permissible once final judgment had been entered in the Board's suit.

5. OfFice OF Legal Pol'y, U.S. DeP'T OF Justice, REPORT to THE ATTORNEY GENERAL-THE CONSTITUTION IN THE YEAR 2000: ChOICES AHEAD IN CONSTITUTIONAL INTER PRETATION 179-80 (1988) [hereinafter REPORT TO MEESE]. Even commentators who do not embrace a categorically separationist reading of the Constitution may advocate increased presidential supervision of domestic policymaking in order to enhance the political accountability of regulatory policy. See, e.g., Peter L. Strauss \& Cass R. Sunstein, The Role of the President in Informal Rulemaking, 38 ADMIN. L. REV. 181, 190 (1986).

6. Of the various initiatives catalogued in note 4, supra, the Reagan and Bush Administrations were ultimately successful in implementing centralized presidential oversight of regulatory policymaking and barring consent decrees that constrained the future exercise of administrative discretion. They also successfully opposed, on separation of powers grounds, proposed legislation that would have subjected high officials in a President's first administration to second-term confirmation. See Constitutionality of Proposed Legislation Requiring Renomination and Reconfirmation of Executive Branch Officers upon the Expiration of a Presidential Term, 11 Op. Off. Legal Counsel 25, 26 (1987). Only the first of these initiatives received any widespread publicity, and, even with respect to regulatory oversight, the separation-of-powers implications were probably little understood by the general public. The Administrations' ultimate legal positions did not prevail regarding executive privilege against Congress, executive authority to ignore laws it thinks unconstitutional, ex parte contacts during agency adjudication, or the discharge of independent commissioners. With the possible exceptions of the Watt and Gorsuch imbroglios, however, each of these episodes raised serious questions of principle that received little or no general public attention. 
though the issues involved are serious and conceivably have important implications both for the performance of government and for the citizenry's faith in that government.

I propose here to compare the philosophies of categorical separation and checked separation with respect to a single concern: the capacity of government structure to promote executive fidelity to the rule of law. The Iran-Contra scandal and its aftermath will provide the laboratory for my comparison. My thesis, which I believe is well illustrated by Iran-Contra, is that the advantages offered by checks and balances in promoting the rule of law are significant, and that categorical separation tends to subvert, rather than encourage, executive conformity to law. Promoting the rule of law is, of course, only one concern of sound governance; political accountability, policy coherence, and efficiency require separate consideration. Yet, the link between the rule of law and the separation of powers is at the core of both the historic and the current appeal of separation of powers as a principle of government structure. ${ }^{7}$ I doubt most citizens would consciously trade much by way of legality to achieve other governmental virtues.

Part I below reviews the history of Iran-Contra and subsequent prosecutions, noting various accusations of official abuse levied respectively against the Reagan Administration and the Office of Independent Counsel during the course of these events. Part II then elaborates on categorical and checked separationism as competing schools of constitutional interpretation, linked in turn to different visions of government. Part III fleshes out what I take to be an attractive conception of the "rule of law" ideal and suggests how that conception might be linked theoretically to either categorical or checked separationism as principles of governance. Part IV then shows how the analytic hypotheses of Part III are reflected in competing analyses of the constitutionality of independent counsel generally, and in competing assessments of the actual performance of the Iran-Contra Independent Counsel. I then conclude that Iran-Contra fully substantiates the theoretical link between the rule of law and checks and balances in government.

\section{The IRAN-Contra SCANDAL AND ITS PROSECUTOR: EXPERIMENTS in CATEgorical and CheCKed SeParation}

The Iran-Contra scandal helps to illuminate the likely relationship between categorical separationism, if implemented fully in American governance, and the rule of law. It is an instructive experience, in part, because the President's

7. On current developments, see J.F. Brown et al., Toward the Rule of Law, RFE/RL RESEARCH REP., July 3, 1992, at 1-56 (surveying developments in Eastern Europe); José E. Alvarez, Promoting the "Rule of Law" in Latin America: Problems and Prospects, 25 GEO. WASH. J. INT'L L. \& ECON. 281 (1991). 
actions in this foreign policy episode occurred under conditions strongly resembling those that categorical separationism would promote in domestic affairs. That is, our Presidents have been largely successful in foreign policymaking in acting as if the Constitution vests in them a significant scope of foreign policymaking power which is discretionary, confidential, relatively immune to congressional scrutiny (at least as to process), and subject to judicial review only in rare instances. ${ }^{8}$ Only when the Iran-Contra events went awry did "checked separationism" appear in the person of the independent counsel. Even here the principle was thwarted, in a sense, by President Bush's exercise of his wholly discretionary pardon power. Rethinking the various stages of these events permits a considered judgment, at least as to this one episode, with regard to the correspondence between rule of law government and contesting conceptions of separation of powers.

The outline of the Iran-Contra affair is by now familiar, although the details of the many relevant transactions and decisionmaking processes defy easy summary. The Reagan Administration-through the staff of the National Security Council (NSC)-began a covert fund-raising campaign for the Nicaraguan Contras in $1984^{\circ}$ in response to Congress's enactment of a series of statutory prohibitions called the Boland Amendments, which barred the use of federal funds to aid the Contras. ${ }^{10}$ In the Summer of 1985, the NSC staff in charge of the Contra operation also took responsibility for implementing President Reagan's decision to permit Israel to sell U.S. missiles to Iran. ${ }^{11}$ Israel had proposed the transactions, which the White House hoped would lead to improved relations with Iran and to the release of U.S. hostages in Lebanon. ${ }^{12}$ Under the operational leadership of Lt. Col. Oliver North, U.S.M.C.,

8. The current state of the President's foreign policy powers is well examined in HAROLD HONGJU KoH, The National SECURITy CONSTItUTION: SHARING POWER AFTER THE IRAN-CONTRA AfFaIR 117149 (1990). A potentially critical difference between foreign and domestic policymaking exists, of course, because contemporary proponents of categorical separationism still concede the need for the President to rest his domestic policymaking - as opposed to his foreign affairs initiatives-on statutory authority, however general. Given the breadth of domestic policymaking discretion actually delegated by many statutes, however, and the likely impossibility of repealing many such delegations over a President's veto, the claim made for the inherent administrative authority of the President in domestic affairs is by no means a modest one.

For "rule of law" purposes, however, the problem with the constitutional claims of categorical separationists may lie less with the broad policymaking discretion they would attribute to the President in domestic affairs than with the further insistence on confidentiality and judicial nonreviewability. The exercise of presidential policymaking control need not be especially troublesome for the rule of law if it is both relatively public and open to formal review.

9. REPORT OF THE CONGRESSIONAL COMMITTEES INVESTIGATING THE IRAN-CONTRA AFFAIR, H.R. REP. No. 433 (S. REP. No. 216), 100th Cong., 1st Sess. 4, 37-41 (1987) [hereinafter IRAN-ConTRA REPORT]; PRESIDENT's SPECIAL REVIEW BD., THE TOWER COMMISSION REPORT 453-59 (1987) [hereinafter TOWER REPORT].

10. For a compilation of the texts and legislative histories of every version of the Boland Amendment enacted between 1982 and 1986, see 133 CONG. REC. H4584-87 (daily ed. June 15, 1987) (statement of Rep. Alexander).

11. IRAN-CONTRA REPORT, supra note 9, at 6; TOWER REPORT, supra note 9, at 148-50.

12. IRAN-CONTRA REPORT, supra note 9, at 6-7. 
the NSC group began diverting the U.S. profit from these sales to a nongovernmental organization designed by private citizens Richard Secord and Albert Hakim to engage in covert activities to support the Contras. ${ }^{13}$ Not only did the participants avoid notifying Congress of any aspect of these operations, but a number of officials lied to congressional committees concerning the Administration's efforts on behalf of the Contras. ${ }^{14}$ The initiative began to unravel in November 1986, when a Lebanese weekly newspaper, Al Shiraa, disclosed a meeting in Tehran between Iranian President Rafsanjani and National Security Adviser Robert McFarlane. ${ }^{15}$ The story was leaked by an Iranian faction opposed to Rafsanjani, whom the faction hoped to embarrass. ${ }^{16}$

The implementation of both prongs of the Iran-Contra effort involved apparent violations of law, although the full scope of illegality remains a subject of debate. It is undisputed that Administration officials repeatedly made false statements to congressional committees by denying Administration involvement in aiding the Contras. ${ }^{17}$ The joint majority report for the House

13. Id. at $4,7-9,343$.

14. Id. at 5 .

15. Bretton G. Sciaroni, Boland in the Wind: The Iran-Contra Affair and the Invitation to Struggle, 17 Pepp. L. Rev. 379, 379-80 (1990).

16. IRAN-CONTRA REPORT, supra note 9, at $520 \mathrm{n} .^{*}, 561$ (Minority Report).

17. A catalogue of official attempts to deceive Congress with respect to the Iran-Contra events would include the following:

Elliott Abrams: Abrams pled guilty to withholding information from the Senate Foreign Relations Committee on October 10, 1986 regarding his knowledge that Lt. Col. Oliver L. North had been in contact with people supplying the Contras, and had previously asked and encouraged them to supply the Contras. He further admitted withholding information from the House Intelligence Committee on October 14, 1986, when he was asked about a newspaper report that Saudi Arabia was helping supply the Contras. Ronald J. Ostrow, Abrams Pleads Guilty in Contra Aid Cover-up, L.A. TIMES, Oct. 8, 1991, at A1.

Alan D. Fiers, Jr.: The former chief of the Central Intelligence Agency's (CIA) Central American Task Force pled guilty to withholding from Congress on October 14, 1986 his knowledge that the airplane of Eugene Hasenfus, shot down on October 5, 1986, was part of Lt. Col. North's Contra supply operation, and to telling Congress falsely on November 26, 1986 that he had no knowledge of arms sales to Iran or the diversion of profits to Contra aid. Excerpts From Statement on Former C.I.A. Aide, N.Y. TIMES, July 10, 1991, at A16.

Clair E. George: A jury convicted the former head of the CIA's operations directorate of (a) making a false statement to the House Permanent Committee on Intelligence on October 14, 1986, when he said he had no idea about former CIA employee Felix Rodriguez's role in the Contra resupply operation; and (b) misinforming the Senate Intelligence Committee on December 3, 1986 when he said he did not know what role Lt. Col. North or Richard V. Secord had played in providing funds to the Contras. Neil A. Lewis, Ex-Spy Chiefls Convicted of Lying To Congress on Iran-Contra Affair, N.Y. TIMES, Dec. 10, 1992, at $\mathrm{Al}$.

Robert C. McFarlane: The former National Security Adviser pled guilty to withholding information from Congress about the activities of Lt. Col. North and other members of the National Security Council staff in three 1985 letters to House committees, and to making a false statement on December 8, 1986, before the House Foreign Affairs Committee, in which he claimed that he had no concrete knowledge that another country had contributed money to the Contras. Philip Shenon, McFarlane Admits Withholding Data on Aid to Contras, N.Y. TIMES, Mar. 12, 1989, at 1.

Oliver L. North: North admitted helping to compose letters sent to members of Congress in September, 1985 in which he falsely denied that he had either helped to raise private funds for the Contras or had provided them with tactical advice. He also admitted repeating the lies in a White House meeting with members of Congress in August 1986. Robert L. Jackson, North Lied to Congressmen, Defends Actions, L.A. Times, Apr. 8, 1989, at 1. A jury subsequently convicted North for helping to prepare a false 


\section{Presidents, Pardons, and Prosecutors}

and Senate Select Committees investigating the Iran-Contra affair also concluded that the Contra aid effort violated the Boland Amendments, and, more controversially, that the independent financing of a government program in circumvention of an appropriations bar was unconstitutional. ${ }^{18}$ As for the arms sales to Iran, it is clear that those sales failed to comply with the terms of the Arms Export Control Act (AECA), ${ }^{19}$ which would have required, among other things, a promise from Iran not to retransfer the U.S. missiles.

chronology for Congress about a potentially illegal 1985 shipment of Hawk missiles to Iran, and for altering and shredding government documents concerning that sale. He was further convicted of altering and destroying National Security Council records, primarily about his work for the Contras when the Boland Amendments were in force. George Lardner, Jr., North Guilty on 3 Counts in Iran-Contra Affair: Ex-NSC Aide ls Acquitted On 9 Charges, WASH. Post, May 5, 1989, at A1.

John M. Poindexter: A jury found the former National Security Adviser guilty of (a) conspiring, from the Spring of 1985 to December 1986, to obstruct congressional inquiries by using false chronologies, making false statements to congressional committees, and destroying official documents in connection with the Iran-Contra initiatives; (b) obstructing Congress by signing false and misleading letters to the House Foreign Affairs, Intelligence and Armed Services Committees in July and August 1986 stating that the Administration had complied with the "spirit and letter of the law" barring direct government aid to the Contras in Nicaragua; (c) assisting in November 1986 to prepare a chronology of the government's role in the sale of arms to Iran that falsely reported that no U.S. official had learned of an Israeli shipment of U.S.-made Hawk antiaircraft missiles to Iran until January 1986, when President Reagan signed a letter approving the U.S. involvement; and (d) falsely stating to the House and Senate Intelligence Committees on November 21, 1986 that he did not know about the November 1985 sale of Hawk missiles to Iran until January 1986 and did not know until November 1986 that anyone in the government had prior knowledge of the sale. David Johnston, Poindexter is Found Guilty of All 5 Criminal Charges for Iran-Contra Cover$U p$, N.Y. TIMES, Apr. 8, 1990, at 1.

In addition to the foregoing deceptions for which Administration officials were convicted, former Defense Secretary Caspar Weinberger was indicted for falsely telling Congress that he kept no regular notes about his Pentagon activities; falsely testifying in 1987 that he was unaware that Saudi Arabia had provided millions of dollars in contributions to the Contras; falsely denying that he had known of the November 1985 sale of Hawk missiles to lran; and falsely denying his knowledge of discussions about whether the United States would replenish from Pentagon supplies the missiles that Israel was selling to Iran. Although President Bush's pardon of Weinberger obviated any trial on these charges, they appear to be sustained by over 1700 pages of Weinberger's diary notes that were discovered subsequent to his making the statements at issue. One Weinberger Charge Dismissed; Four Others Remain, STAR TRIB., Dec. 12, 1992, at 7A; Ronald J. Ostrow, Weinberger to Face New Charge in Iran-Contra Case Investigation: Officials Say Indictment Will Revive Allegations that the Former Defense Secretary Tried to Hide Notes About Meetings Conceming the Affair, L.A. TIMES, Oct. 10, 1992, at A2; David Johnston, Case Against Weinberger: Written in His Own Hand, N.Y. TIMES, June 18, 1992, at A1; David Johnston, Weinberger Faces 5 Counts In Iran-Contra Indictment, N.Y. TMMES, June 17, 1992, at Al.

18. IRAN-CONTRA REPORT, supra note 9, at 413. Substantial uncertainty remains concerning the extent to which arms sales profits truly were diverted to Contra aid. In 1989, then-law professor, now Assistant Attorney General Walter Dellinger wrote that the media's focus on the Boland Amendment controversy had unfortunately blurred the fact that, "[a]t its core, United States v. North is an embezzlement case." As Dellinger observed:

Most of the $\$ 30$ million went into secret Swiss bank accounts controlled by North and codefendant Richard Secord, and intermediary in the arms deal. As far as the indictment's embezzlement count is concerned, it doesn't matter whether the money went from there to the contras, or to Secord and Albert Hakim (another intermediary), or for that matter to the United Way or Mother Teresa. Since the money did not belong to the defendants, they were not free to use it for anything other than the authorized Iranian arms sale.

Walter Dellinger, Ollie North's Farewell Pefformance: Case Closed, ThE NEw REPUblic, Jan. 9, 1989, at 14 .

19. Arms Export Control Act, Pub. L. No. 90-629, 82 Stat. 1320 (1968) (codified as amended in scattered sections of 22 U.S.C.). 
The President could have avoided the AECA by authorizing a transfer of U.S. arms as part of an intelligence operation under the National Security Act. ${ }^{20}$ That Act, however, would have required timely notice to Congress of the arms sale. ${ }^{21}$ Further, the President would have needed to have made a "finding" under the Hughes-Ryan Amendment to the Foreign Assistance Act that the intelligence operation was "important to the national security of the United States. "22 Such a finding was reduced to writing (and then destroyed), however, only after the first sale of arms to Tehran had already been consummated, and was thus of dubious legality. ${ }^{23}$ Finally, the Administration, prior to the Al Shiraa disclosures, never notified Congress of either the Contra aid operation or the arms sales to Iran. In both instances, the Administration arguably violated the timely notice requirements imposed by the Intelligence Authorization Act for Fiscal Year 1981. ${ }^{24}$

Preliminary investigation of the Iran-Contra episode prompted Attorney General Meese to seek the judicial appointment of an independent counsel under the Ethics in Government Act. ${ }^{25}$ The man appointed, prominent Republican Lawrence Walsh, a retired federal judge and former American Bar Association President, has since been the steady target of critical attacks in Congress and the press. According to his detractors, Walsh's performance, rather than vindicating the rule of law, has demonstrated the evils of discretion run riot. It is fair to say that much of this criticism is premised on the argument that Iran-Contra represented no major wrongdoing and, in any event, Congress drove the Administration to its malfeasance. ${ }^{26}$ Yet, there are more particularized complaints. Primary among those voiced by commentators in the Congressional Record is that Mr. Walsh has taken too long and spent too

20. 50 U.S.C. $\S 415(2)(\mathrm{b})(\mathrm{i})$ (1988).

21. 50 U.S.C. $\S 413(\mathrm{~b})(1988)$.

22. Hughes-Ryan Amendment to the Foreign Assistance Act of 1961, Pub. L. No. 87-195, 75 Stat. 424 (1961) (codified as amended at 22 U.S.C. $\$ 2422$ (1988)) (repealed 1991).

23. IRAN-CONTRA REPORT, supra note 9, at 195, 379; Ethan Bronner, Poindexter Convicted on All Counts, Boston GloBE, Apr. 8, 1990, at 1.

24. Intelligence Authorization Act for Fiscal Year 1981, Pub. L. No. 96-450, tit. 4, § 407(b)(1), 94 Stat. 1975, 1981 (1980) (codified at 50 U.S.C. § 413 (1988)).

25. Ethics in Government Act of 1978, Pub. L. No. 95-521, tit. 6, 92 Stat. 1824, 1867 (codified as amended at 28 U.S.C. $\$ 591-99$ (1988)).

26. See infra text accompanying note 144 . 
much money to produce too few results. ${ }^{27}$ When Walsh secured the indictment of former Defense Secretary Caspar Weinberger, accusations intensified that he sought only a political vendetta against President Reagan, ${ }^{28}$ and that his efforts represented, in the oft-repeated phrase of Oliver North, no more than "the criminalization of political differences." 29 This allegation was supported by the timing of certain revelations regarding Weinberger's private notes concerning Iran-Contra policy meetings. Walsh alleged, late in the 1992 presidential election campaign, that the notes belied President Bush's prior explanations of his own role in and knowledge of the Iran-Contra affair. ${ }^{30}$ Critics suggested that the independent counsel was a zealot, single-mindedly and unrestrainedly pursuing his designated quarry: victims to be overmatched by the virtually unlimited financial resources of the federal government. ${ }^{31}$

27. Michael Hedges, Quixotic Quest?-As Critics Steam, Lawrence Walsh Pushes on with Iran-Contra Probe, WASH. TMES, reprinted in 138 CONG. REC. E427 (daily ed. Feb. 26, 1992) (statement of Rep. Broomfield) (noting that after spending $\$ 30$ million in three years, Walsh's cases were either dropped, overturned or resulted in small fines/sentences); Walsh Fiasco Drags On, MEMPHIS COMMERCIAL APPEAL, May 20, 1992, reprinted in 138 CONG. REC. S7163, 7164 (daily ed. May 21, 1992) (statement of Sen. Cochran) (" $\$ 30$ million probe has put exactly one person behind bars"); Robert H. Bork, Against the Independent Counsel, COMMENTARY, reprinted in 139 CONG. REC. S2518, 2520 (daily ed. Mar. 9, 1993) (statement of Sen. Dole) (stating that Walsh's six-year, $\$ 35$ million record "ranges from poor to disastrous"); 138 CoNG. REC. S8428 (daily ed. June 18, 1992) (statement of Sen. Gorton) ("Mr. Walsh has achieved little but at great cost."); 138 CONG. REC. E2097, 2098 (daily ed. July 7, 1992) (statement of Rep. Duncan) (claiming that $\$ 40-50$ million was spent "with no benefit to the taxpayers whatsoever").

28. 138 CoNG. REC. S8428 (daily ed. June 18, 1992) (statement of Sen. Gorton) (claiming that Walsh's primary goal was "to search for evidence of President Reagan's supposed involvement in a conspiracy with respect to the arms-for-hostages deal"); Walsh's Hostage, WALL ST. J., reprinted in 138 CONG. REC. S8428 (daily ed. June 18, 1992) (statement of Sen. Gorton) (remarking that he had little doubt that Weinberger's indictment was for refusal to help "Lawrence Walsh make a case against Ronald Reagan"); Walsh's Silver Lining, WALL ST. J., reprinted in 138 CONG. REC. E2097, 2098 (daily ed. July 7, 1992) (statement of Rep. Duncan) ('It's clear to anyone who reads the [indictment] that [Walsh's assistant, Craig Gillen's] goal is less to convict Mr. Weinberger of lying than to imply a conspiracy to protect Ronald Reagan. "); 138 CoNG. REC. S7398 (daily ed. June 3, 1992) (statement of Sen. Dole) ("Mr. Walsh's agents told Mr. Weinberger that unless he testified that President Reagan was involved in violations of the law during Iran-Contra, they would see that Secretary Weinberger was indicted by the grand jury.").

29. For example, Secretary of State James A. Baker stated on CNN's Newsmaker Saturday (June 20, 1992) that the criminal case against Weinberger "flows from the fact that more and more in this country we are tending to criminalize our policy differences." Weinberger Defended, NEWSDAY, June 21, 1992, at 16. See also Walsh's Hostage, supra note 28 , reprinted in 138 CONG. REC. at S8429 (claiming that "criminalization of politics" is demonstrated by Weinberger indictment and that Weinberger is "hostage to Mr. Walsh's political goals."); infra note 179 .

30. According to one report, Bush's supporters "singled out the [Weinberger] indictment as the event that damaged [Bush] most in the closing hours of the race," and Republicans on the Senate Judiciary Committee demanded that Attorney General William Barr seek the appointment of an independent prosecutor to investigate Walsh's motivations for issuing the indictment. One Weinberger Charge Dismissed, supra note 17.

31. Hedges, supra note 27 , reprinted in 138 CoNG. REC. at E428 (critics claim Walsh is vindictive and overzealous; "legally bizarre prosecution forces its middle-class victims to spend millions of dollars to hire lawyers to shut Mr. Walsh down"); Bork, supra note 27, reprinted in 139 CoNG. REC. at S2518 (arguing that the unlimited budget built into the independent counsel statute facilitates "the certainty of pain and injustice to many innocent people" and that absurd misdemeanor charges leveled against Elliott Abrams support claim that "Walsh and his staff went after Abrams because they badly needed trophies to justify their existence"); 138 CoNG. REC. S8428 (daily ed. June 18, 1992) (statement of Sen. Gorton) (asserting that Walsh used "extended proceedings to exact a penalty through legal bills rather than a conviction" against suspects who refused to plead). 
This portrayal of Walsh, if true, would be alarming given the intentions behind the Ethics in Government Act. From 1978 until 1992, that Act provided the framework for the appointment of independent counsel to investigate highlevel executive wrongdoing. The Act provided that, whenever the Attorney General received specific information alleging a serious federal offense by a high-level executive official or member of the President's campaign team, the Attorney General would have ninety days to conduct a preliminary investigation. ${ }^{32}$ Unless the Attorney General was willing to certify that, according to the results of the probe, no further investigation was necessary, she would be obliged to apply to a special division of the U.S. Court of Appeals for the D.C. Circuit for the appointment of an independent counsel to take over the investigation. ${ }^{33}$ Within her specified jurisdiction, the independent counsel had all the powers of a Justice Department prosecutor, ${ }^{34}$ except that such counsel did not generally report to the Attorney General ${ }^{35}$ and, barring impeachment, could be removed "only by the personal action of the Attorney General and only for good cause, physical disability, mental incapacity, or any other condition that substantially impairs the performance of such independent counsel's duties." 36

For our purposes, the attack on Walsh is theoretically significant because the charges against him present a direct counterpoint to any critique of categorical separationism as manifested in the executive branch's behavior during the Iran-Contra episode. If the criticisms of Walsh are well-founded, they would demonstrate the shortcomings of checked separationism as an organizing principle for governance. The attack would show that, by creating a novel checking mechanism beyond presidential control to serve the rule of law, Congress ironically created an unaccountable tyrant who has magnified political disagreements into criminal charges and subordinated the interest of fairness to his own aggrandizement. ${ }^{37}$

\section{II. "Categorical" Versus "Checked" SEPARATION OF POWERS}

\section{A. Contending Approaches to Constitutional Interpretation}

The Iran-Contra experience provides a concrete background against which to assess the relationship between two conceptions of the separation of powers

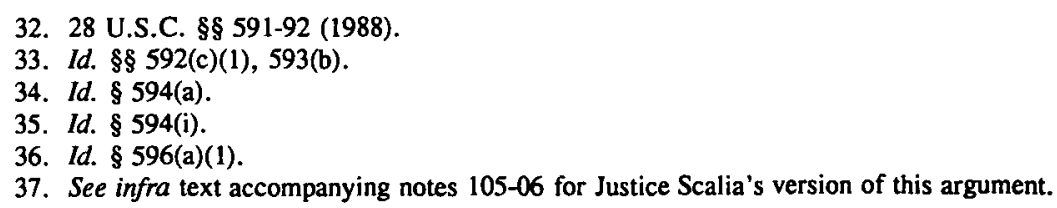


and a rule of law ideal. Both of those conceptions, however, and the rule of law ideal itself require more precise definition before a full evaluation is possible.

At one level, "categorical" and "checked" separationism most conspicuously represent two different approaches to the legal resolution of separation of powers disputes. Although it uses different labels, a 1988 Justice Department "white paper" offers a helpful starting point in distinguishing the two orientations. Categorical separationism is:

rigorous with regard to classification. Under this approach, the Court must determine, first, whether the function or office at issue should be classified as legislative, executive, or judicial in character and, second, whether the function or office is, in fact, being performed by an official of the appropriate branch. The Court under this approach would not be tolerant of efforts by one branch to perform functions assigned to the others, and it would view with skepticism efforts to fuse functions by creating independent offices or agencies that share the attributes of more than one branch. ${ }^{38}$

In contrast, a "checks and balances" or checked separationist view is:

less rigorous with regard to the classification of functions. . . Under this approach, the Court may still inquire whether the function or office at issue is essentially legislative, executive, or judicial in character and whether the function or office is being performed by an official of the corresponding branch, but a negative answer to the latter inquiry is not necessarily fatal. Rather, the . . . approach requires the Court to inquire further whether the assignment of duties to a person outside the appropriate branch of government impermissibly impedes that branch in exercising its constitutionally assigned functions. Because the ultimate question would be one of degree, rather than of kind, the Court's analysis . . . necessarily involves a balancing of the interests it perceives to be at stake. ${ }^{39}$

In sum, a breach of formal separation under the "checks and balances" view would not necessarily be unconstitutional if it left each branch capable of implementing its constitutional authorities. Moreover, as the Supreme Court has stated in one oft-cited opinion in the "checks and balances" mode, an initiative of one branch that did potentially impede the performance of another might still be upheld if "justified by an overriding need to promote objectives within the constitutional authority of" the challenged branch. ${ }^{40}$ Such balancing is inconsistent with the categorical separationist approach.

In any given dispute, what motivates the difference between categorical and checked separationism may be nothing more than an honest disagreement about the proper interpretation of a particular constitutional phrase. Some commentators, for example, contend that the Article II vesting of "executive power" in the President was historically intended to convey to the President a specific

38. REPORT TO MEESE, supra note 5, at 178.

39. Id. at 178-79.

40. Nixon v. Administrator of General Services, 433 U.S. 425, 443 (1977). 
category of authorities that no other branch may limit or regulate. ${ }^{41}$ Their rigorous separationism is simply the consequence of their particular version of originalist interpretation of the vesting clause. Others, including myself, regard the phrase as lacking any such clear definition. We interpret the historical record as contemplating a fair degree of flexibility in the organization of government administration, so long as the specific presidential functions expressly mentioned in Article II are left to the President. ${ }^{42}$ A more flexible separation of powers theory, based on this reading, simply implements a different conclusion as to accurate originalist interpretation.

It seems fair to say, however-especially given the political context for the last decade's separation of powers battles-that many "categorical separationists" and many "checked separationists" perceive more to be at stake in their disagreement than sound reading. Recent "categorical separationists" have consistently supported expansive views of executive power. ${ }^{43}$ Attributing greater power to the President, and immunizing that power from the regulation of others, is said to have the virtue of promoting presidential accountability. ${ }^{44}$ That is, to the extent the President's powers are undiluted, all observers of the President-legislators, voters, other countries-will know whom to hold

41. See, e.g., Lee S. Liberman, Morrison v. Olson: A Formalistic Perspective on Why the Court Was Wrong, 38 AM. U. L. REV. 313 (1989).

42. See, e.g., Gerhard Casper, An Essay in Separation of Powers: Some Early Versions and Practices, 30 WM. \& MARY L. REv. 211 (1989); William B. Gwyn, The Indeterminacy of the Separation of Powers and the Federal Courts, 57 GEO. WASH. L. REV. 474 (1989) [hereinafter Gwyn, Federal Courts]; William B. Gwyn, The Indeterminacy of the Separation of Powers in the Age of the Framers, 30 WM. \& MARY L. REV. 263 (1989) [hereinafter Gwyn, Age of the Framers]; Peter M. Shane, Independent Policymaking and Presidential Power: A Constitutional Analysis, 57 GEO. WASH. L. REV, 596 (1989).

43. See generally Steven G. Calabresi \& Kevin H. Rhodes, The Structural Constitution: Unitary Executive, Plural Judiciary, 105 HARV. L. REV. 1155 (1992); Liberman, supra note 41. It is important to underscore, however, that the connection between a categorical view of the separation of powers and executive expansionism is not inevitable. It depends upon a particular reading of the "executive power" vested by Article II of the Constitution. U.S. CONST. art. II. A "categorist" might conclude, contrary to Calabresi, Rhodes, and Liberman, that the President is categorically barred from ever implementing domestic policy that is not expressly authorized by Congress. Certainly Justices Black and Douglas, who denied the President's power to order the seizure of steel mills in Youngstown Sheet \& Tube Co. v. Sawyer, 343 U.S. 579 (1952), represented the most stringently categorical thinking on the Court in that case. The other opinions, whether for or against the President, could best be understood as competing analyses of the implications of sound "checks and balances" reasoning on the unusual facts of Youngstown.

44. REPORT TO MEESE, supra note 5, at 178; $c f$. Frank B. Cross, The Surviving Significance of the Unitary Executive, 27 Hous. L. REV. 599, 731 (1990) (suggesting legal recognition of "the significance of the essentially unitary executive . . . in order to safeguard public accountability"); Douglas W. Kmiec, Of Balkanized Empires and Cooperative Allies: A Bicentennial Essay on the Separation of Powers, 37 CATH. U. L. REV. 73, 75 (1987) (separation of powers produces "greater responsiveness of the government to the citizenry"); Miller, supra note 2, at 56 ("the centralization and coordination that a unitary executive makes possible are likely to be more conducive to efficient government than is a splintered executive branch subject to various checks and balances beyond those set forth in the text of the Constitution."); Martin H. Redish \& Elizabeth J. Cisar, "If Angels Were to Govem": The Need for Pragmatic Formalism in Separation of Powers Theory, 41 DUKE L.J. 449, 453 (1991) (claiming that abandoning separation of powers as a method of preventing concentration of power would dramatically increase the vulnerability of "the concept of representative and accountable government"); Wilkey, supra note 2, at 533 (urging that restoring "true constitutional government" would vest greater responsibility in the Chief Executive). 


\section{Presidents, Pardons, and Prosecutors}

responsible for the success or failure of policies subject to the President's control. The clarity of his responsibility will facilitate holding him to account.

"Checked separationists," by contrast, may or may not be fans of an energetic presidency, but do believe that discretion regarding the strength of the executive lies in significant respects with Congress. Checked separationism emphasizes values of deliberation and flexibility, as well as a conception of accountability that depends as much on the branches' interconnectedness as on the clarity and definitiveness of any one branch's role. ${ }^{45}$ Such an approach need not deny that the Constitution vests certain irreducible powers in particular branches. It does, however, construe the element of irreducibility narrowly, and is guided by the general precept that constitutional ambiguities should be resolved to preserve the branches' mutual accountability.

As it happens, both tendencies in separation of powers thought have some claim to a Madisonian pedigree. ${ }^{46}$ The reason lies in an ambiguity within Madison's famous exegesis of the separation of powers. Madison's analysis commences with the premise that a constitutional separation of powers is essential to the protection of human freedom. Among Madison's most famous observations is the assertion: "The accumulation of all powers, legislative, executive, and judiciary, in the same hands, whether one, a few, or many, and whether hereditary, self-appointed, or elective, may justly be pronounced the very definition of tyranny. ${ }^{47}$ As restated by Joseph Story a generation later, separation "is indispensable to public liberty. ${ }^{.48}$

Yet, it is crucial to note that Madison uttered his condemnation of accumulated powers in a paper that sought to defend the incompleteness of the separation of powers actually contemplated by the draft Constitution. Far from connecting the ideal of liberty with a theory of completely separated powers, Madison attributed to Montesquieu the more limited argument that no branch of government should exercise "the whole power of another department." 49 Story's restatement is admirably clear:

[W]hen we speak of a separation of the three great departments of government . . we are to understand this maxim in a limited sense. It is not meant to affirm, that they must

45. See, e.g., Yvette M. Barkesdale, The Presidency and Administrative Value Selection, 42 AM. U. L. REv. 273 (1993); William V. Luneburg, Civic Republicanism, the First Amendment, and Executive Branch Policymaking, 43 ADMIN. L. REV. 367 (1991).

46. Compare REPORT TO MEESE, supra note 5, at 178 ("The Madisonian road . . . may lead to less efficiency in government, but it assures greater responsibility by the respective branches of government for their constitutionally assigned tasks. The Madisonian road is rigorous with respect to classification.") with Nixon v. Administrator of General Services, 433 U.S. 425, 441-42 (1977) ("Appellant's argument is . . . inconsistent with . . . the contemporary realities of our political system. . . [T] [Te more pragmatic, flexible approach of Madison in the Federalist papers and later of Mr. Joseph Story was expressly affirmed by this court only three years ago ....").

47. The Federalist No. 47, at 301 (James Madison) (Clinton Rossiter ed., 1961).

48. JOSEPH STORY, COMMENTARIES ON THE CONSTITUTION OF THE UNITED STATES § 267, at 197 (Ronald D. Rotunda \& John E. Nowak eds., S. Carolina Acad. Press 1987).

49. The FEDERALIST No. 47, at 303 (James Madison) (Clinton Rossiter ed., 1961). 
be kept wholly and entirely separate and distinct, and have no common link of connexion or dependence, the one upon the other, in the slightest degree. The true meaning is, that the whole power of one of these departments should not be exercised by the same hands, which possess the whole power of either of the other departments, and that such exercise of the whole would subvert the principles of a free constitution. ${ }^{50}$

Madison's rationale for imperfect separation went further, of course, than the observation that fidelity to Montesquieu did not demand more. He argued that some sharing of power was necessary to assure the very protection of liberty that the separation of powers was intended to achieve: "[U]nless these departments be so far connected and blended as to give each a constitutional control over the others, the degree of separation which the maxim requires, as essential to a free government, can never in practice be duly maintained. " ${ }^{\text {II }}$ In other words, the protection of freedom does not demand only the general separation of legislative, executive, and judicial functions: the Constitution must also "contriv[e] the interior structure of the government as that its several constitutional parts may, by their mutual relations, be the means of keeping each other in their proper places. ${ }^{~}{ }^{2}$ From this observation springs the justification for the host of overlapping and shared powers that our Constitution dictates, including Congress's power to remove officers of the United States, ${ }^{53}$ the President's power to veto legislation, ${ }^{54}$ and the courts' power to review both legislation and administrative action. ${ }^{55}$ Unless the three great departments "be so far connected and blended as to give to each a constitutional control over the others," there is no effective way of "guard[ing] against those encroachments which lead to a tyrannical concentration of all the powers of government in the same hands. ${ }^{56}$

Categorical separationists would implement this analysis in a near-syllogistic way. They start from the premise that separation of powers is necessary for liberty. Second, they contend that the express constitutional exceptions to complete separation are justified only by the contribution they ultimately make to keeping the separation of powers intact. Therefore, proper implementation of the Madisonian design requires categorical implementation of the separation of powers principle, leaving any breaches or exceptions to be narrowly construed and permitted only as they serve the ultimate cause of separation. This approach does not deny the existence of constitutional checks, but rather insists on their narrow construction. In applying this learning to actual problems, a categorical separationist need not inquire beyond this tightly focused frame-

50. STORY, supra note $48, \S 267$, at 197.

51. The Federalist No. 48, at 308 (James Madison) (Clinton Rossiter ed., 1961).

52. THE FEDERALIST No. 51, at 320 (James Madison) (Clinton Rossiter ed., 1961).

53. See THE FEDERALIST No. 65 (Alexander Hamilton) (discussing impeachment).

54. See The Federalist No. 73 (Alexander Hamilton) (discussing presidential veto power).

55. See THE FeDERalist No. 78 (Alexander Hamilton) (discussing judicial power).

56. The Federalist No. 48, at 313 (James Madison) (Clinton Rossiter ed., 1961). 
work into the institutional consequences of practices challenged as violations of the separation of powers. For a categorical separationist, the whole of the founders' purposes may be reduced to "separation über alles. "57

The "checks and balances" response, however, can be seen as an effort to contextualize Madison's exegesis within the larger argument of The Federalist. Although Madison's separation of powers discussion emphasizes freedom from tyrannical rule as an essential goal of the new Constitution, this was not to be the new government's only virtue. It was critical to Madison that the government be "oblige[d] to control itself," but fundamental also that the Constitution "enable the government to control the governed. ${ }^{\text {"58 }}$ The Federalist does not equate the government that governs best with the government that governs least. Rather, it defends our constitutional structure as most likely to produce legislative decisions that will counteract the forces of faction, ${ }^{59}$ administration that will be energetic and of the utmost integrity, ${ }^{60}$ and judicial interpretation embodying scrupulous and politically independent judgment. ${ }^{61}$ From this perspective, the separation of the three branches is but part of a larger scheme of checks and balances through which government is rendered both safe and efficacious. It is the coexistence of multiple goals linked to sound governance that frequently necessitates the very balancing that categorical separationists eschew.

In proffering a distinction between two interpretive tendencies, I do not intend to suggest that all adherents of a categorical separationist view and all adherents of a checks and balances view will, respectively, reach identical conclusions on all separation of powers questions. Especially within the "checks and balances" school, there may be significant disagreement about the degree to which constitutional language or historical evidence settles a particular separation of powers dispute in a way that precludes further balancing. One may reject the core view of categorical separationists that "executive power," for example, has a fixed meaning which significantly limits congressional

57. See, e.g., Justice Scalia's dissent in Morrison v. Olson, arguing that:

The Court devotes most of its attention to such relatively technical details as the Appointments Clause and the removal power, addressing briefly and only at the end of its opinion the separation of powers. . . . I think that has it backwards. Our opinions are full of the recognition that it is the principle of separation of powers, and the inseparable corollary that each department's "defense must . . . be made commensurate to the danger of attack," ... which gives comprehensible content to the Appointments Clause, and determines the appropriate scope of the removal power. Thus, while I will subsequently discuss why our appointments and removal jurisprudence does not support today's holding, I begin with a consideration of the fountainhead of that jurisprudence, the separation and equilibration of powers.

487 U.S. 654, 703-04 (1988) (quoting THE FEDERALIST No. 51, at 322 (James Madison) (Clinton Rossiter ed., 1961)).

58. THE Federalist No. 51, at 322 (James Madison) (Clinton Rossiter ed., 1961).

59. See generally THE FEDERALIST No. 10 (James Madison).

60. See generally THE FEDERALIST Nos. 70, 72 (Alexander Hamilton).

61. See generally THE FEDERALIST No. 78 (Alexander Hamilton). 
authorities, but regard the Presentment Clauses ${ }^{62}$ as sufficiently clear to invalidate all legislative vetoes, regardless of functional impact. ${ }^{63}$ Pragmatism, in other words, does not necessarily exclude all formalism. Yet, given the current range of most hotly disputed separation of powers issues, the central direction of each school of thought is highly predictable. Categorical separationists regard the President as substantially insulated from congressional regulation; "checks and balances" adherents, much less so.

\section{B. Contending Visions of Government}

So long as potential government corruption remains a significant public concern, the role of independent counsel exemplified by Lawrence Walsh is likely to endure. ${ }^{64}$ Given the attacks on the independent counsel described earlier, we have thus likely identified one way in which a checked separationist regime in this country may continue to differ from a regime that categorical separationists would prefer.

To make a confident comparison of the relative contributions of checked separationism and categorical separationism to rule of law government, it would be ideal if we could catalogue all the institutional differences that would be likely as between a checked and a categorical separationist government. It is impossible to do so definitively, however, because separation of powers theory can provide only an incomplete prediction of actual government practice. The fact that a President might be charged with a broad range of policymaking powers pursuant to a categorical separationist conception of the Constitution would still leave him authority, for example, to adopt a highly diffuse style of management and to encourage subordinate administrators to be responsive to Congress's policy preferences. In such a case, strong separation in theory could co-exist with a wide distribution of actual political power. Conversely, Congress-even under a checks and balances view that accords it constitutional primacy in policymaking-might prefer to delegate authority broadly to administrative agencies and to grant the President generous power to conform the agencies' policy choices to his own, highly centralized direction. ${ }^{65}$ Congress could even abdicate its "checking" roles, leaving the Presi-

62. U.S. CoNST. art. I, \$ 7, cls. $2-3$.

63. Peter M. Shane, Conventionalism in Constitutional Interpretation and the Place of Administrative Agencies, 36 AM. U. L. REV. 573, 585-86 (1987); Peter M. Shane, The Separation of Powers and the Rule of Law, 30 WM. \& MARY L. REV. 375, 380-81 n. 27 (1989).

64. As of November 18, 1993, the House Judiciary Committee had reported favorably on a bill to reauthorize the independent counsel process and the full Senate had approved a similar bill. Holly Idelson, Senators Set Aside Suspicions, Vote for Counsel Law Renewal, 51 CONG. Q. WKLY. REP. 3205 (1993).

65. Congress might, indeed, be more inclined to vest certain kinds of administrative discretion in the President if it were assured that the President did not dispute Congress's capacity to promote the review of presidential implementation either through public access to relevant documents or lawsuits based on broad theories of standing. 
dent a range of authority nearly equivalent to a categorical separationist regime. ${ }^{66}$ In sum, at least in theory, to know that ours is a government in which "categorical separationism" or "checks and balances" dominates as constitutional interpretation would be to know only a limited amount about the government's actual operation and potential.

Still, this degree of uncertainty does not leave us entirely without clues as to what is at stake here. We can already observe the sorts of institutions that have evolved under checked separationism. We can examine initiatives either implemented or advocated by categorical separationist Presidents and other commentators, and review the behavior of Presidents in those areas of policymaking, such as foreign affairs, where conventional practice most closely approximates the executive expansionists' categorical vision. Although it is hypothetically possible for the actual distribution of institutional power to be starkly at odds with the government's constitutional allocation of policymaking authority, a close relationship is more likely. Therefore, some reasonable speculation as to the shape of checked separationist and categorically separationist regimes seems possible, on the hypotheses that the prevalence of different conceptions of the separation of powers would likely (a) generate different institutional arrangements within government and (b) ramify into some more general ethos or attitude towards government among those actually in power.

Recently enacted and recently proposed initiatives consistent with the "checked separationist" view include several measures to increase executive accountability to Congress. For example, requirements that agencies or their inspectors general submit reports to Congress on demand, or submit reports simultaneously to both the President and Congress, have grown steadily more numerous. ${ }^{67}$ In a stark case, Congress amended the statutory office of CIA Inspector General in 1990 to make that official a presidential appointee, but

66. Given the current laxness of the nondelegation doctrine, Congress would be little constrained by the formal constitutional requirement that its enactments be specific enough to constrain administrative discretion in a meaningful way. See generally JERRY MASHAw ET AL., ADMINISTRATIVE LAW: THE AMERICAN PUBLIC LAW SYSTEM 51-79 (3d ed. 1992). Intriguingly, however, at least some scholars detected a shift towards narrower delegations in legislation enacted by the Democrat-controlled Congress under President Reagan. Sidney Shapiro \& Robert Glicksman, Congress, the Supreme Court, and the Quiet Revolution in Administrative Law, 1988 DUKE L.J. 819.

67. E.g., Agriculture and Water Policy Coordination Act, Pub. L. No. 101-624, tit. 14, §1482, 104 Stat. 3622 (1990) (codified at 7 U.S.C. $\$ 5502$ (Supp. Ill 1991)); Immigration Act of 1990, Pub. L. No. 101-649, tit. 3, § 302(a) \& tit. 6, § 603(a)(24), 104 Stat. 4978, 5030, 5036 (codified as amended at 8 U.S.C. § 1254a (Supp. III 1991)); National Defense Authorization Act for Fiscal Years 1992 and 1993, Pub. L. No. 102-190, div. A, tit. 3, § 314(a), 105 Stat. 1290, 1336 (1991) (codified as amended at 10 U.S.C. $\S 2466$ (Supp. IV 1992)); Business Opportunity Development Reform Act of 1988, Pub. L. No. 100-656, tit. 4, $\$ \S 406,408,102$ Stat. 3853, 3876, 3877 (1988) (codified at 15 U.S.C. $\$ 636(j), 639(\mathrm{e})$ (Supp. III 1991)); Small Business Act of 1986, Pub. L. No. 99-443, \& 3, 100 Stat. 1120 (1986) (codified as amended at 15 U.S.C. $\S 638$ note (Supp. IV 1992)); Coastal Barrier Improvement Act, Pub. L. No. 101-591, §§ 8, 14, 104 Stat. 2931, 2937, 2941 (1990) (codified at 16 U.S.C. \$§ 3503 note, 3506 (Supp. III 1991)); Intelligence Authorization Act for Fiscal Year 1986, Pub. L. No. 99-169, tit. 4, § 401(a), 99 Stat. 1002, 1004 (1985) (codified as amended at 50 U.S.C. $\$ 414$ (1988)). 
subject to advice and consent of the Senate. ${ }^{68}$ The Intelligence Authorization Act also permits the chair or ranking member of the Intelligence Committee of either house of Congress to demand reports from the Inspector General, ${ }^{69}$ a provision that President Bush attacked as unconstitutional. ${ }^{70}$ Such requirements are problematic from a categorical separationist perspective, because that perspective tends to regard all aspects of executive branch management as strictly within the President's purview. For Congress to elicit information from administrative agencies without presidential clearance appears, from a categorical perspective, to be an intrusion into the exclusive province of executive power. On the other hand, from a "checks and balances" view, disclosure requirements are justifiable for the assistance they provide to legislative oversight.

A "checks and balances" view also sustains congressional use of the socalled "independent agency" device to mitigate the President's direct policy control over certain administrative functions. So-called independent agencies are typically headed by a collegial body, no more than a bare majority of whom may represent any one political party. They ordinarily serve staggered terms longer than a presidential term. Perhaps most important, the agency heads are removable only for "cause," and it is conventional understanding that cause would not include commissioners' unwillingness to follow the President's policy directions in preference to the contrary policy initiatives of the commissioners, so long as the latter are also statutorily authorized. ${ }^{71}$

In contrast, the most important innovation of the 1970s and 1980s reflecting a categorical separationist view of executive power is the centralization of presidential regulatory oversight functions in the Office of Management and Budget. ${ }^{72}$ Prior to the 1970s, White House efforts to provide unified oversight of agency regulatory activity were both intermittent and limited in scope. After President Reagan substantially increased OMB's managerial prerogatives vis-àvis executive agencies, Congress sought to interpose checking mechanisms, such as public access to communications to and from OMB concerning regulatory initiatives. ${ }^{73}$ President Bush resisted Congress's efforts on this score,

68. Intelligence Authorization Act, Fiscal Year 1990, Pub. L. No. 101-193, tit. 8, $\S 801,103$ Stat. 1711 (codified as amended 50 U.S.C. \$ 403q (Supp. IV 1992)).

69. 50 U.S.C.A. $\$ 403 q$ (d)(4) (Supp. III 1991).

70. Statement on Signing the Intelligence Authorization Act, Fiscal Year 1990, 25 WEEKLY CoMP. PRES. DOC. 1851 (Nov. 30, 1989).

71. This understanding, however, has never been authoritatively resolved in court. As Professor Geoffrey Miller has pointed out, a judicial interpretation of "for cause" removal clauses that would permit discharges based on direct disobedience of a presidential policy order would obviate the central constitutional controversy concerning independent agencies. Miller, supra note 2, at 86-90.

72. See generally Harold H. Bruff, Presidential Management of Agency Rulemaking, 57 GEO. WASH. L. REV. 533 (1989).

73. Kitty Dumas, Administration Deal Pushes Paperwork Reduction Act, 48 CoNG. Q. WKLY. REP. 3602 (1990); Kitty Dumas, Congress or the White House: Who Controls the Agencies?, 48 ConG. Q. WKLY. REP. 1130 (1990). 
shifting important oversight authority away from OMB and into a vice-presidential task force even less susceptible than OMB to public and congressional scrutiny. ${ }^{74}$ Efforts to encompass the independent agencies within such oversight schemes would further promote the categorical separationist vision. Including in any such initiative greater accommodation for congressional oversight of the executive coordination process would provide a "checked separationist" form of counterbalance.

The Supreme Court has recently shown signs of another way in which it might give voice to the categorical separationist vision. Over the last few decades, federal plaintiffs have tried increasingly to challenge alleged programmatic failures by the executive branch to enforce entire statutory programs. ${ }^{75}$ In two recent decisions, the Supreme Court appears to have made such suits substantially more difficult by interpreting narrowly the Court's "standing" doctrine ${ }^{76} \mathrm{~A}$ narrow reading of that doctrine is rooted in the premise that federal courts are constitutionally limited to deciding "cases" and "controversies" that substantially resemble common law forms of action. No matter how great the illegality about which a litigant complains, a lawsuit against the government is permissible only if the complaint alleges a concrete injury that is personal to the plaintiff, a causal connection between the challenged conduct and the alleged injury, and a reasonable likelihood that the court could redress the alleged injury through the remedy sought.

The rub is that, if the executive subverts the law through outright nonenforcement, strong demonstrations of personalized injury and likelihood of redress to particular individuals become especially difficult. Moreover, to the extent that federal courts treat these standing requirements as constitutionally dictated, Congress is barred from creating procedurally innovative statutory causes of action through which the courts may be deployed as a check on

74. On Bush's rejection of congressional demands for more open regulatory review, see Kitty Dumas, White House Pulls the Rug Out on Regulatory Review Deal, 48 CONG. Q. WKLY. REP. 1475 (1990).

In a June, 1990 memorandum, President Bush assigned to the President's Council on Competitiveness-chaired by Vice-President Quayle-the regulatory oversight responsibilities formerly vested in a "Presidential Task Force on Regulatory Relief" that Bush had chaired during the Reagan Administration. On the history of the Council, see Regulatory Review Sunshine Act, S. ReP. No. 256, 102d Cong., 2d Sess. 19-37 (1991).

75. The grandparent of such litigation is Adams v. Richardson, 356 F. Supp. 92 (D.D.C. 1973), aff d in part, 480 F.2d 1159 (D.C. Cir. 1973) (en banc), challenging programmatic non-enforcement of Title VI of the Civil Rights Act of 1964 by the Office of Civil Rights of the then-Department of Health, Education and Welfare under President Nixon. The apparent concluding chapter of this litigation was Women's Equity Action League v. Cavazos, 906 F.2d 742 (D.C. Cir. 1990).

76. Lujan v. Defenders of Wildlife, 112 S. Ct. 2130 (1992); Lujan v. National Wildlife Federation, 110 S. Ct. 3177 (1990). For a still valuable pre-Lujan (and therefore overly optimistic for plaintiffs) discussion of the issues posed by "inaction" suits, see Peter H.A. Lehner, Note, Judicial Review of Administrative Inaction, 83 COLUM. L. REV. 627 (1983). 
executive nonfeasance. ${ }^{77}$ To the categorical separationist, this is an acceptable-indeed, unavoidable-result because the Court must be limited to its constitutionally described category of dispute resolution; any ultra vires lawsuits against the government would be impermissible intrusions into the powers of the elected branches. ${ }^{78}$ To the checked separationist, this would be a distressing trend because it leaves accountability for programmatic nonenforcement entirely to political processes which may be preoccupied with other issues and difficult to mobilize.

What these examples suggest, of course, is a logical relationship between theory and practice. To the degree checked or categorical separationism dominates within government as a prevailing conception of the separation of powers, we are likely to see a greater or lesser proliferation, respectively, of formal mechanisms by which each branch can restrain the discretionary acts of the others and by which each elected branch can reduce the other's capacity to dominate government policymaking. The correspondence of theory to practice will not be perfect. Categorical separationists do not deny that the Constitution specifies shared and overlapping powers in some respects. Checked separationists would acknowledge that, to some degree, the Constitution assigns powers to the respective branches that the other branches may not control, and that any initiative by one branch to check another must be rooted in a power constitutionally vested in the checking branch. Moreover, both categorical separationist-executive expansionists and checked separationistlegislative supremacists may be led on occasion by competing considerations of party or policy to endorse initiatives inconsistent with their preferred principles. ${ }^{79}$ Still, many politicians will seek in an intellectually honest way to determine which understanding of our governing principles is soundest and at least sometimes to pursue whichever vision they find most persuasive. ${ }^{80}$ It is hardly plausible that the commitment of political actors to one or another vision of the separation of powers will make no difference in the attitudes that these leaders bring to the process of governing.

Further, the attitudes of those in charge of each branch will surely communicate themselves to the numerous staff personnel substantially responsible for

77. See generally Gene R. Nichol, Jr., Justice Scalia, Standing, and Public Law Litigation, 42 DUKE L.J. 1141 (1993); Richard J. Pierce, Jr., Lujan v. Defenders of Wildlife: Standing as a Judicially Imposed Limit on Legislative Power, 42 DUKE L.J. 1170 (1993).

78. See generally Marshall J. Breger, Defending Defenders: Remarks on Nichol and Pierce, 42 DUKE L.J. 1202 (1993); John G. Roberts, Jr., Article III Limits on Statutory Standing, 42 Duke L.J. 1219 (1993).

79. It has obviously been critical to the precise shape of recent separation of powers battles that the Democrats have controlled both houses of Congress for 19 of the last 25 years, while the Republicans have held the White House for 21 years during that same period. It is no surprise, therefore, that Republicans have lately been more vocal in defending strong Presidents, and Democrats more enthusiastic about checks and balances, in contrast to the New Deal period.

80. Cf. Daniel A. Farber \& Philip P. Frickey, Law and Public Choice: A Critical introducTION 29-33 (1991) (discussing studies showing that legislator's ideology provides a better predictor of legislative votes than the economic effects of such votes on constituents or campaign contributors). 


\section{Presidents, Pardons, and Prosecutors}

much day-to-day governing. ${ }^{81}$ Adherents to "categorical separation" will express their expectation that Congress should exercise restraint in deploying its oversight tools; they will regard executive cooperation with Congress as largely discretionary. Adherents of "checked separation" will discuss executive discretion as a trust largely vested by Congress and view Congress's occasional forbearance from vigorous oversight as a tentative expression of confidence, which can be revoked. In the innumerable personal interactions between agents of President and Congress, such attitudes will surely be exhibited, with a significant, even pervasive effect on the tone of governance, although that effect may be subtle vis-à-vis any particular transaction. ${ }^{82}$ In this sense, even if elected officials cannot always act in a manner fully consistent with their separation of powers vision, within each branch the philosophy "at the top" is likely to generate its own ethos of governance in which either oversight is the norm and discretion is to be deployed cautiously, or discretion is the norm and oversight is largely to be left to electoral politics.

\section{LINKING SEPARATION OF POWERS to THE RULE OF LAW}

\section{A. The "Rule of Law" in Principle}

The Federalist, widely regarded as our greatest native text on political theory, was based upon the tacit premise that sound governmental structure is essential to the realization of a nation's substantive values-among them, values of liberty, self-determination, and cooperative national development. It is equally well established that the "rule of law" ranks among the Constitution's fundamental value commitments, and that the U.S. version of the separation of powers was intended to honor that commitment. ${ }^{83}$ The question whether any particular conception of the separation of powers is more likely than others to facilitate or even promote the rule of law is thus utterly central to our constitutional tradition.

But the task of relating government structure to a rule of law ideal faces a difficult problem. The concept of "rule of law" is as elusive as it is funda-

81. Cf. Marshall B. Clinard, Corporate Ethics and Crime: The Views of Middle ManageMENT 131-44, reprinted in M. DAVID ERMANN \& RICHARD J. LUNDMAN, CORPORATE AND GOVERNMENtal Deviance: Problems of Organizational Behavior in Contemporary Society 81, 82 (3d ed. 1987).

82. For an analysis suggesting an interrelationship between the elected branches' respective convictions as to their institutional prerogatives and the negotiations attending executive privilege claims during the first Reagan Administration on behalf of Interior Secretary James Watt and EPA Administrator Anne Gorsuch, see Shane, Legal Disagreement, supra note 4; Peter M. Shane, Negotiating for Knowledge: Administrative Responses to Congressional Demands for Information, 44 ADMIN. L. REV. 197 (1992).

83. See generally Paul R. Verkuil, Separation of Powers, the Rule of Law and the Idea of Independence, 30 WM. \& MARY L. REV. 301 (1989). 
mental. To engage in an intelligible inquiry as to the relationship between theories of government structure and the "rule of law," we must specify the conception of the "rule of law" to which we aspire..$^{84}$

Perhaps the most basic tenet of a strong "rule of law" regime is that the exercise of all power within the system is, in principle, limited by law. ${ }^{85}$ Marbury $v$. Madison elaborated on this tenet by insisting that government power in the United States be exercised in a manner consistent with the Constitution, treating the Constitution as a written source of positive law. ${ }^{86}$ In the same spirit, Justice Jackson wrote of the requirement that the President:

\begin{abstract}
“. . shall take Care that the Laws be faithfully executed . . . . That authority must be matched against words of the Fifth Amendment that "No person shall be . . . deprived of life, liberty or property, without due process of law ...." One gives a governmental authority that reaches so far as there is law, the other gives a private right that authority shall go no farther. These signify about all there is of the principle that ours is a government of laws, not of men, and that we submit ourselves to rulers only if under rules. ${ }^{87}$
\end{abstract}

Even before the Bill of Rights added the Due Process Clause to which Jackson refers, the original text signaled various aspects of the founders' understanding of the rule of law. The very separation of the lawmaking power from the powers of implementation through administration and adjudication was deemed essential to the rule of law. ${ }^{88}$ Article I further banned ex post facto laws and bills of attainder ${ }^{89}$ signaling the centrality of individual fairness to our rule of law model. The prohibition against suspending habeas corpus except in narrowly defined exigent circumstances ${ }^{90}$ enhanced the U.S. commitment to individual rights, as did the Constitution's protections for an independent judiciary. ${ }^{91}$ Authorizing Congress to impeach and remove officers of the United States created an important institutional check upon official

84. In suggesting "rule of law" government as an ideal worthy of pursuit, I do not mean to sound oblivious to objections either that a rule of law regime may permit certain powerful interests to dominate society unfairly, or that the rule of law ideal is itself incoherent. The first objection is true; observance of the rule of law is insufficient by itself to insure a just society. On the other hand, if we were to compare two societies equally unjust in every way except that one followed the rule of law and one did not, observance of the rule of law would be a strong reason to prefer the former. The second objection deals with issues of legal and political theory beyond the bounds of this project. Readers seeking a thoughtful argument in favor of the coherence of the rule of law ideal should see ANDREW ALTMAN, CRITICAL LEGAL STUDIES: A LibERAL CRITIQUE (1990).

85. Id. at 13,25 .

86. 5 U.S. (1 Cranch) 137, 170 (1804).

87. Youngstown Sheet \& Steel Co. v. Sawyer, 343 U.S. 579, 646 (1952) (Jackson, J., concurring) (quoting U.S. CONST. art. II, \& 3 and U.S. CONST. amend. V, respectively).

88. See generally The Federalist No. 47 (James Madison); William B. GWYN, The MEANING of THE SEPARATION OF POWERS 128 (1965); MAURICE J.C. VILE, CONSTITUTIONALISM AND THE SEPARATION OF POWERS 159-60 (1967); Verkuil, supra note 83.

89. U.S. CoNST. art. I, $\S 9$, cl. 3 .

90. U.S. CoNST. art. I, $\S 9$, cl. 2.

91. U.S. CONST. art. III, $\S 1$ (providing that judges shall "hold their Offices during good Behaviour" and shall not have their compensation reduced while in office). 
corruption, ${ }^{92}$ a check deemed so important as to be exempted from the reach of the President's pardon power. ${ }^{93}$ By barring the executive suspension of statutes through the "faithful execution clause, ${ }^{n 94}$ the founders committed our government to the supremacy of law. In short, the U.S. conception of the "rule of law" embraced not only obedience to rules, but also carefully designed institutions for deliberative rulemaking and disinterested execution, a promise of individual rights and fundamental fairness, and a general aspiration to responsible official action. The "rule of law" vision that I am describing is thus as much a conception of an "ethic of accountability" as it is a conception of an ethic of following the law.

No government's claim to such "rule of law" status, however, can rest on the loftiness of constitutional phrasing. This is so for two closely interconnected reasons. The more familiar is that the Constitution cannot execute itself. Human beings must implement the constitutional text, and the text's operational, rather than denotative, meaning determines the document's efficacy. What gives life to the Constitution's rule of law protections is less their express commands than the spirit in which they are enforced. Thus, for example, one could imagine a nation governed by the words of our constitutional text, which nonetheless used impeachment as a fairly routine form of political check on judges, or in which the requirements of "public safety" justifying the suspension of habeas corpus were construed generously on behalf of the government. The fact that neither of these developments has occurred testifies less to the precise wording of the Constitution than to the enduring cultural expectations surrounding the constitutional text.

But a second factor is equally important. Public officials face literally countless decisions each day that have the potential to injure individuals, to defeat people's legitimate expectations of government, or to undermine the law generally. All but a fraction of these occur at a low enough level or within a sufficiently discretionary framework that no realistic likelihood exists of checking those decisions through judicial review, legislative oversight hearings, or impeachment. Thus, government's fidelity to law depends not merely on

92. The Constitution vests the sole "Power of Impeachment" in the House of Representatives. U.S. CoNST. art. $1, \S 2, \mathrm{cl} .5$. This process, which produces "articles of impeachment" resembling an indictment, triggers the "sole Power" of the Senate to "try all Impeachments." U.S. ConST. art. I, § 3, cl. 6. Should an impeachment trial result in a conviction, "judgment . . . shall not extend further than to removal from Office; and disqualification to hold and enjoy any Office of honor, Trust or Profit under the United States: but the Party convicted shall nevertheless be liable and subject to Indictment, Trial, Judgment and Punishment, according to Law." U.S. CoNST. art. I, $\$ 3, \mathrm{cl}$. 7. As interpreted by the Senate, this provision requires removal from office as an automatic consequence of conviction, but disqualification from holding office requires a separate vote. PROCEDURE AND GUIDELINES FOR IMPEACHMENT TRIALS IN THE UNTTED States Senate, S. Doc. No. 33, 99th Cong., 2d Sess. 95, 99, 101 (1986).

93. U.S. CONST. art. II, $\$ 2, \mathrm{cl} .1$.

94. U.S. CONST. art. II, $\S 3$.

95. U.S. CONST. art. I, $\S 9, \mathrm{cl} .2$ (limiting suspension of the privilege of the writ of habeas corpus to "Cases of Rebellion or Invasion [when] the public Safety may require it"). 
the spirit in which the Constitution's discrete protections for law are implemented; it depends equally on the spirit in which officials exercise their authority in circumstances where formal mechanisms of accountability are remote. Madison wrote: “If men were angels, no government would be necessary. If angels were to govern men, neither external nor internal controls on government would be necessary. ${ }^{96}$ But the truth is that no set of controls on government, external or internal, can defeat the vice of officials determined, systemically or in concert, not to be angels.

It is because the tasks of our government officials are so laden with discretion, both de jure and de facto, that Justice Frankfurter's insight into the nature of the rule of law is so important:

[L]aw is not a code of fettering constraints, a litany of prohibitions and permissions. It is an enveloping and permeating habituation of behavior, reflecting the counsels of reason on the part of those entrusted with power in reconciling the pressures of competing interests. Once we conceive of "the rule of law" as embracing the whole range of presuppositions on which government is conducted . . . the relevant question is not, has it been achieved, but, is it conscientiously and systematically pursued. ${ }^{97}$

To see government under the "rule of law" in this light is to appreciate how important are the attitudes of government officials to its realization. ${ }^{98}$ To ask whether any conception of the separation of powers is more likely than others to facilitate the rule of law in an American context is necessarily to ask which theory, given prevailing cultural and political conditions, is most likely to foster the appropriate "enveloping and permeating habituation of behavior ... on the part of those entrusted with power."

\section{B. Theorizing Links to the Separation of Powers}

As between "checks and balances" and "categorical separationism," the former's claim to priority in securing the rule of law would seem, from one point of view, both conventional and straightforward. It is a common premise

96. The Federalist No. 51, at 322 (James Madison) (Clinton Rossiter ed., 1961).

97. Felix Frankfurter, John Marshall and the Judicial Function, Address at a Conference Held at Harvard Law School on the Occasion of the Bicentennial of John Marshall (Sept. 22, 1955), in GovERNMENT UNDER LAW 6, 28 (Arthur E. Sutherland ed., 1956).

98. A distinguished commission recently reached the identical conclusion with regard to the entire field of government ethics regulation:

If ethics regulation is to achieve the responsible and careful use of power upon which our common welfare depends, it must be at least as concerned with inducing government employees to be their best, as it is with trying to block them from being their worst . . . . One essential piece of this regulatory reorientation is the conscious cultivation of an institutional ethical culture: Public employees should be functioning within a value structure that leads them to honorable behavior out of a sense of professional pride and a conviction of the rightness of such behavior, rather than out of a fear of sanctions.

ABA Comm. on Gov't Standards, Keeping Faith: Government Ethics \& Government Ethics Regulation, 45 ADMIN. L. REV. 287, 294 (1993). 
of U.S. administrative law that officials whose actions are most susceptible to public exposure, deliberation, and evaluation in different forums are most likely to make decisions that can be publicly defended under widely held substantive and procedural norms. ${ }^{99}$ A government designed pursuant to a philosophy of checks and balances would seem more likely to generate formal mechanisms-such as independent counsel-for disciplining official decisionmaking in just these ways. Moreover, the ethos of checking and balancing is logically consistent with an institutional culture of restraint in which officials internalize an expectation that preferences and interests other than their own need be consulted in the formulation of legitimate public policy. ${ }^{100}$ If absolute power corrupts absolutely, then power disciplined by the power of others would seem best calculated not to corrupt.

Yet, we can make some reply on behalf of categorical separationism. For starters, it must be recalled that categorical separationists do not deny all checks and balances, but merely deny the availability of newly created checking mechanisms that would breach the formal dictates of separation. Current executive expansionists do not deny the power of impeachment, Congress's control of appropriations, ${ }^{101}$ the susceptibility of corrupt officials to criminal prosecution, or the availability of ordinary judicial review to protect individuals from violations of their rights inflicted through the executive's improper discharge of its ministerial duties to those individuals. Moreover, press coverage and the oversight of legislative committees remain as indirect political checks on official conduct. Where categorical separationism differs from a checks and balances view is chiefly in ascribing to the executive a wide range of decisionmaking authority that is discretionary, ${ }^{102}$ confidential and relatively immune to congressional scrutiny (at least as to process), ${ }^{103}$ and subject

99. This presumably is the premise animating the Freedom of Information Act, 5 U.S.C. § 552 (1988); the Government in the Sunshine Act, 5 U.S.C. $\$ 552 b$ (1988); and the Federal Advisory Committee Act, 5 U.S.C. app. $\S \S 1-15$ (1988); as well as, in part, the general requirement that agency regulatory decisions-whether rules or orders-be promulgated and explained publicly. 5 U.S.C. \$§ 553(b), (c) (informal rulemaking), 557(c) (record of formal proceedings) (1988).

100. For a systematic defense of the position that the Constitution embodies a fundamental commitment that political power not be exercised solely on the ground that those in authority have the de facto power to pursue their own personal or factional interests, see generally Cass R. Sunstein, Naked Preferences and the Constitution, 84 COLUM. L. REV. 1689 (1984). The link between the government of laws ideal and the obligation of officials to make decisions reflecting social values beyond their personal desires and interests is urged in Shane, Legal Disagreement, supra note 4, at 485-92.

101. Of course, "[a]ppropriations acts, like other legislation, must comport with the Constitution." Neal E. Devins, Regulation of Govermment Agencies Through Limitations Riders, 1987 DUKE L.J. 456, 474. 2 .

102. See, e.g., the scope of administrative discretion ascribed to the President in Miller, supra note

103. For Attorney General Smith's assertion of categorical presidential authority to determine that executive documents can be withheld from Congress, see Assertion of Executive Privilege in Response to a Congressional Subpoena, 5 Op. Off. Legal Counsel 27, 30-31 (1981); Assertion of Executive Privilege in Response to Congressional Demands for Law Enforcement Files, 6 Op. Off. Legal Counsel 31, 34-35 (1982). See also Public Citizen v. U.S. Dep't of Justice, 491 U.S. 440, 488 (1989) (Kennedy, J., concurring) (arguing that presidential appointment power would invalidate any administrative statute that 
to judicial review only in limited instances. ${ }^{104}$ The additional critical difference is the likely categorical separationist view that suits against the executive be limited to disputes similar in form to common law forms of action.

Within the President's fairly generous realm of constitutionally vested executive discretion, categorical separationists insist that reliance on the President's self-discipline is both inevitable and sufficient to fulfill the rule of law ideal. Justice Scalia put the matter this way in his dissent to Morrison $v$. Olson, the decision upholding the constitutionality of independent counsel appointed under the Ethics in Government Act:

\begin{abstract}
We should say here that the President's constitutionally assigned duties include complete control over investigation and prosecution of violations of the law . . . . Is it unthinkable that the President should have such exclusive power, even when alleged crimes by him or his close associates are at issue? No more so than that Congress should have the exclusive power of legislation, even when what is at issue is its own exemption from the burdens of certain laws. No more so than that this Court should have the exclusive power to pronounce the final decision on justiciable cases and controversies, even those pertaining to the constitutionality of a statute reducing the salaries of the Justices. A system of separate and coordinate powers necessarily involves an acceptance of exclusive power that can theoretically be abused. . . . The checks against any branch's abuse of its exclusive powers are twofold: First, retaliation by one of the other branch's use of its exclusive powers . . . . Second, and ultimately, there is the political check that the people will replace those in the political branches ... who are guilty of abuse. ${ }^{105}$
\end{abstract}

In other words, because discretionary power is inevitable in our system of government, the possibility of abuse of power cannot defeat a claim that ours is a government of laws.

But categorical separationism goes further than this. According to at least some "categorists," it is undue checking and balancing, not categorical separation, that portends the greater threat to the rule of law. For example, to the extent that innovative mechanisms of accountability resemble the independent counsel statute, Congress may ultimately be encouraged to create structures or mechanisms that are all but exempt from political accountability and which, therefore, can breed their own sort of lawlessness. Justice Scalia hypothesized such potential abuse of the independent counsel's power:

An independent counsel is selected, and the scope of his or her authority prescribed, by a panel of judges. What if they are politically partisan, as judges have been known to be, and select a prosecutor antagonistic to the administration, or even to the particular individual who has been selected for this special treatment? There is no remedy for that, not even a political one. . . . The independent counsel thus selected proceeds to assemble

could potentially inhibit "the President's freedom to investigate, to be informed, to evaluate, and to consult during the nomination process").

104. See, e.g., Lujan v. Defenders of Wildlife, 112 S. Ct. 2130, 2145 (1992) (ruling that congressional vesting of standing in citizens generally to contest unlawful government action would impinge on executive authority to take care that the laws be faithfully executed).

105. Morrison v. Olson, 487 U.S. 654, 710-11 (1989) (Scalia, J., dissenting). 


\section{Presidents, Pardons, and Prosecutors}

a staff. . . . [I]n the nature of things this has to be done by finding lawyers who are willing to lay aside their current careers for an indeterminate amount of time, to take on a job that has no prospect of permanence and little prospect for promotion. One thing is certain, however: it involves investigating and perhaps prosecuting a particular individual. Can one imagine a less equitable manner of fulfilling the Executive responsibility to investigate and prosecute? What would be the reaction if, in an area not covered by this statute, the Justice Department posted a public notice inviting applicants to assist in an investigation and possible prosecution of a certain prominent person? Does this not invite what Justice Jackson described as "picking the man and then searching the law books, or putting investigators to work, to pin some offense on him"? . . ${ }^{106}$

Justice Scalia was careful not to assert that partisanship or undue antagonisms had tainted the Olson case, but he did insist that "the fairness of a process must be adjudged on the basis of what it permits to happen, not what it produced in a particular case. ${ }^{107} \mathrm{He}$ would presumably extend that insight to a more general assessment of "checks and balances" separationism as a constitutional theory.

Categorical separationists might also discern a threat to the rule of law in the simple proliferation of interbranch checking mechanisms. If we can legitimately analogize to an argument proffered against regulation in other contexts, the generation of further rules and checking mechanisms might have the perverse effect of creating an ethos in which the literal satisfaction of positive law and the clearing of all formal bureaucratic hurdles is all the obeisance that officials are willing to pay the "rule of law." 108 Categorical separationism accepts the inevitability of discretion and so, its proponents might argue, it may promote a culture of governance in which officials take their discretionary powers most seriously precisely because all are aware that the rule of law depends on their individual conscientiousness. In contrast, checked separationism tolerates, even encourages, multiple checks on discretion, but these may foster an overreliance on formal mechanisms and a concomitant thoughtless assumption that any behavior that has not been checked is ipso facto appropriate-or at least not worth worrying about. ${ }^{109}$

It has also been claimed in favor of categorical separationism that the sorts of checks imposed on the executive by a Congress unconstrained by categorical limits do not promote faith in government, but defeat it. In 1982 testimony before Congress in opposition to renewing the independent counsel law, thenAssociate Attorney General Rudolph Giuliani argued:

106. Id. at 729-30 (Scalia, J., dissenting).

107. Id. at 731 (Scalia, J., dissenting).

108. In evaluating the current state of government ethics regulation, the ABA Committee on Government Standards recently expressed a similar view: "Ethics is in danger of becoming an elaborate legalistic ritual, in which the application of multi-part tests substitutes for the internalization of values, and the establishment of multi-level clearance processes replaces the development of a supportive institutional culture." ABA Comm. on Gov't Standards, supra note 98, at 290.

109. Cf. Eugene Bardach \& ROBert A. KaganM, GoINg By the BOOK: The Problem of REGULATORY UNREASONABLENESS 107-111 (1982). 
[T]o the extent that we as a government require the appointment of a special prosecutor in particular cases, or for the investigation of particular individuals, we erode public confidence in our system's regular processes and we forego opportunities to rebuild the confidence of a skeptical public. ... Special prosecutors . . . may enhance the credibility of a particular prosecutive decision viewed in isolation. But that credibility comes only at the expense of the long term public skepticism which we nurture through an ironclad rule disqualifying those individuals who make every other federal prosecutive decision in this nation. 110

According to Giuliani's view, the invention of new checks for all conflict-ofinterest situations encourages the public to assume that the executive, left to its own devices, will never do the right thing.

The arguments on behalf of two contrasting conceptions of our separation of powers amount to two theoretically coherent sets of claims about the relationship of those conceptions to the rule of law. Categorical separationists regard formal separation as the Constitution's fundamental structural imperative. They would not tolerate congressional or judicial impositions on executive discretion that, in their judgment, breach formal separation and lack an express constitutional imprimatur. Categorical separationists thus deem the checking and balancing mechanisms specified in the Constitution to be exclusive. This conception, they argue, promotes the rule of law by acknowledging the breadth of executive officials' discretion and requiring them to face up to their political accountability for any abuse of it. It promotes faith in government by underscoring the people's willingness to trust their governors and permitting those with authority to do their best even if they could get away with less.

Checked separationists regard checks and balances as the Constitution's fundamental structural imperative. Congressional or judicial impositions on executive discretion are tolerable so long as they reasonably implement powers vested in Congress or the judiciary, ${ }^{111}$ and leave the executive capable of discharging its assigned functions. Checked separationism interprets narrowly the mechanisms of formal separation specified in the Constitution. This conception would promote the rule of law by authorizing Congress and the judiciary to generate checks on the executive to help assure adherence to law. Further, while accepting the inevitability of significant executive discretion, a "checks and balances" ideology promotes a bureaucratic culture in which officials are

110. Amendment of the Special Prosecutor Provisions of Title 28: Hearing on S. 2059 Before the Subcomm. on Administrative Law and Gov't Relations of the House Comm. on the Judiciary, 97th Cong., 2d Sess. 16 (1982) (statement of Rudolph W. Giuliani, Associate Attorney General) [hereinafter Statement of Rudolph W. Giuliani].

111. Because not all checked separationists will likely agree on the powers vested in the particular branches, they probably will disagree to some extent on the range of checking mechanisms that are permissible under the Constitution. It might strengthen checks and balances, for example, to attribute the power to require consent to presidential dismissals to Congress, a line-item veto power to the President, or a power to render advisory opinions to the courts. Yet, a checked separationist might still conclude on other grounds that the current constitutional text cannot reasonably be read to vest any of these powers in the respective branches. 
most attentive to the claims of others based on their disinterestedness and responsibility. The existence of multiple checks, in turn, helps promote public faith in government.

\section{INDEPENDENT COUNSEL AND IRAN-CONTRA REVISITED: WHERE SHOULd THE RULE OF LAW TAKE US?}

\section{A. The General Attack on Independent Counsel}

More than any other domestic issue in the last decade, the debate over the constitutionality and wisdom of creating judicially appointed independent counsel to investigate high-level executive branch wrongdoing has focused public attention on the different emphases of categorical and checked separation of powers theories. ${ }^{112}$ The issue arose briefly at the Thomas confirmation hearings. ${ }^{113}$ It has sparked an enormous law review literature. ${ }^{114}$ The particular uses of independent counsel have involved a dismayingly colorful array of well-publicized (even if not always well-founded) government scandals. ${ }^{115}$

The Carter Administration supported passage of the original Ethics in Government Act of 1978. ${ }^{116}$ President Reagan, although he signed extensions

112. This statement is made in comparison to those other Reagan/Bush initiatives, catalogued in note 4, supra, which were either shorter-lived, as in the Watt and Gorsuch imbroglios with Congress, or simply too arcane to provoke public scrutiny, such as the controversy over discretion-limiting consent decrees. It is my personal impression that the only separation of powers stories that receive press attention comparable to independent counsel investigations are war powers disputes; there are no competitors in purely domestic affairs.

113. Nomination of Judge Clarence Thomas to Be Associate Justice of the Supreme Cour of the United States, Hearings Before the Senate Judiciary Comm., Pt. 1, 102d Cong., 1st Sess. 270-71 (1991).

114. The post-Morrison literature alone includes Stephen L. Carter, The Independent Counsel Mess, 102 HaRv. L. Rev. 105 (1988); A Symposium on Morrison v. Olson: Addressing the Constitutionality of the Independent Counsel Statute, 38 AM. U. L. REV. 255 (1989); Symposium, Separation of Powers and the Executive Branch: The Reagan Era in Retrospect, 57 GEO. WASH. L. REv. 401 (1989) (most notably articles by Gwyn, Shane, and Rosenberg); Edward Susolik, Note, Separation of Powers and Liberty: The Appointments Clause, Morrison v. Olson, and Rule of Law, 63 S. CAL. L. REV. 1515 (1990); Liberman, supra note 41; William L. Weigand III, Note, Morrison v. Olson: Renewed Acceptance For a Functional Approach to Separation of Powers, 16 Hastings ConsT. L.Q. 603 (1989); Keith Werhan, Toward an Eclectic Approach to Separation of Powers: Morrison v. Olson Examined, 16 HASTINGS CoNST. L.Q. 393 (1989).

115. In addition to two confidential inquiries that failed to produce indictments in 1982 and 1987 , independent counsels have been appointed under the Ethics in Government Act to investigate alleged drug abuse by Carter aides Hamilton Jordan and Tim Kraft; alleged racketeering by Reagan Labor Secretary Raymond J. Donovan; allegations of financial misdealings by Reagan Attorney General Edwin Meese III; allegations of lying to Congress by Reagan Assistant Attorney General Theodore B. Olson; alleged unlawful lobbying and perjury by Reagan adviser Michael K. Deaver; alleged unlawful lobbying by Reagan aide Lyn Nofziger; the Iran-Contra affair; the HUD fraud scandal; and the search of Bill Clinton's passport files. Joan Biskupic, Hill Signs Point to Peril for Independent Counsel Law, 50 CoNG. Q. WKLY. REP. 2634, 2635 (1992); Carroll J. Doherty, Independent Counsel Named to Probe Passpon Flap, 50 CoNG. Q. WKLY. REP. 3891, 3891 (1992).

116. Ethics in Government: Message to Congress Urging Enactment of the Proposed Ethics in Government Act of 1977 and Special Prosecutor Legislation, 13 WEEKLY COMP. PRES. DOC. 647 (May 
of the independent counsel section of the Act in $1983^{117}$ and in 1987,118 attacked the Act as unconstitutional. ${ }^{119}$ After the Supreme Court in 1988 expressly upheld the constitutionality of the Act, ${ }^{120}$ the Bush Administration nonetheless persisted in arguing that the Act was unnecessary and harmful. ${ }^{121}$ Because Bush hinted that he would veto the Act's extension in 1992, ${ }^{122}$ and because Senate Republicans effectively blocked floor action on reauthorization in the wake of the House Bank scandal, Congress permitted the Act to lapse pending reconsideration under a new President likely to support the independent counsel mechanism. ${ }^{123}$

The Reagan and Bush Administrations objected to both the judicial appointment of criminal prosecutors and the statutory limit on the removability of an officer assertedly performing an "executive function." These objections, echoed expressly in Justice Scalia's Morrison $v$. Olson dissent, perfectly illustrate categorical separationist thinking. Justice Scalia set forth the framework for the analysis as follows:

Art. II, section 1, cl. 1 of the Constitution provides: "The executive Power shall be vested in a President of the United States." . . [T] executive power, but all of the executive power. It seems to me, therefore, that the

3, 1977).

117. 19 WeEKLy COMP. PRES. DOC. 23 (Jan. 3, 1983).

118. Independent Counsel Reauthorization Act of 1987, 23 WeEkLy CoMP. Pres. Doc. 1526 (Dec. $15,1987)$.

119. Id. at 1526-27. The Justice Department Office of Legal Counsel (OLC) opined in April, 1981 that the Act was facially constitutional, but might be unconstitutional as applied. Specifically, OLC argued that the Act might be unconstitutional if applied where no serious prospect of a conflict of interest was presented with respect to a particular prosecution, either because the alleged criminal violation was petty or the official involved occupied too low a level in the bureaucracy. Memorandum from Larry L. Simms, Acting Assistant Attorney General, Office of Legal Counsel, to the Attorney General regarding the Special Prosecutor Act (Apr. 1, 1981) (on file with author). When he testified the following year concerning the Act's extension, Associate Attorney General Rudolph W. Giuliani expressed constitutional doubts about independent counsel, but opposed extension of the special prosecutor law chiefly on policy grounds. Statement of Rudolph W. Giuliani, supra note 110. In 1987, the Justice Department more forcefully asserted "that there are grave constitutional problems with statutes like the present independent counsel statute insofar as they seek to compromise full legal control by the executive over what, under our Constitution, is the core Executive branch function of investigating and prosecuting crime in the name of the United States." Independent Counsel Amendments Act of 1987: Hearings on H.R. IS20 and H.R. 2939 Before the Subcomm. on Administrative Law and Govermmental Relations of the House Comm. on the Judiciary, 100th Cong., 1st Sess. 435 (1987) (statement of John R. Bolton, Assistant Attorney General, Legislative Affairs). Intriguingly, since leaving the Justice Department, Massachusetts Governor William F. Weld, Assistant Attorney General in charge of the criminal division from 1986 to 1988, has strongly advocated renewal of the independent counsel statute. William F. Weld, Dear New Attomey General: An Open Letter, A.B.A. J., Mar. 1993, at 68, 69.

120. Morrison v. Olson, 487 U.S. 654 (1989).

121. Independent Counsel Reauthorization Act of 1992: Hearing on H.R. 5840 Before the Subcomm. on Administrative Law and Governmental Relations of the House Comm. on the Judiciary, 102d Cong., 2d Sess. 11-26 (1992) (statement of Timothy E. Flanigan, Assistant Attorney General, Office of Legal Counsel).

122. Remarks to the Federalist Society of Philadelphia in Philadelphia, Pennsylvania, 28 WEEKLY COMP. Pres. DOC. 575, 578 (Apr. 3, 1992).

123. Inside Congress, 50 CONG. Q. WKLY. REP. 3481 (1992). 


\section{Presidents, Pardons, and Prosecutors}

decision of the Court of Appeals invalidating the present statute must be upheld on fundamental separation-of-powers principles if the following two questions are answered affirmatively: (1) Is the conduct of a criminal prosecution (and of an investigation to decide whether to prosecute) the exercise of purely executive power? (2) Does the statute deprive the President of the United States of exclusive control over the exercise of that power? ${ }^{124}$

Having answered his own questions affirmatively, Justice Scalia did not regard any further normative discussion to be relevant to a proper resolution of the dispute: "If to describe this case is not to decide it, the concept of a government of separate and coordinate powers no longer has meaning." ${ }^{25}$

Seven members of the Court took a different view. ${ }^{126}$ The majority dismissed the notion that the constitutionality of either an independent counsel's appointment mechanism or the limits on removability could be determined simply through a proper classification of the counsel's function as "executive" or something else. ${ }^{127}$ Instead, the majority concluded that the constitutionality of the challenged features of the independent counsel law depended on their impact on the President's capacity to discharge his constitutionally assigned functions. "[T]he real question," the Court said, "is whether the removal restrictions are of such a nature that they impede the President's ability to perform his constitutional duty, and the functions of the officials in question must be analyzed in that light." 128

Because the majority was less systematic than Justice Scalia in setting forth its precise premises of constitutional interpretation, the opinion leaves some ambiguity as to the underlying nature of the disagreement on the Court. The majority agreed, for example, that at least some aspects of the constitutional challenge to the independent counsel could be resolved through highly formal constitutional reasoning. In permitting judicial appointments of such prosecutors, for example, the Court relied on the literal text of the Constitution, authorizing Congress to vest the appointment of "inferior" officers of the United States in "Courts of Law." 129

Likewise, the majority's and dissent's differing conclusions concerning any infringement on "executive power" might reflect nothing more than disagreement as to the formal definition of that phrase. For Justice Scalia, Article II vests in the President all functions as "executive" that are not performed by court or Congress:

124. Morrison, 487 U.S. at 705 (Scalia, J., dissenting).

125. Id. at 703 (Scalia, J., dissenting).

126. Justice Kennedy did not participate in the decision.

127. 487 U.S. at 695.

128. Id. at 691 .

129. Id. at 670 (discussing U.S. CONST., art. II, § 2, cl. 2 and citing Buckley v. Valeo, 424 U.S. $1,132(1976)$ ). 
In what . . . sense can one identify "the executive Power" that is supposed to be vested in the President (unless it includes everything the Executive Branch is given to do) except by reference to what has always and everywhere-if conducted by government at allbeen conducted never by the legislature, never by the courts, and always by the executive. . . Governmental investigation and prosecution of crimes is a quintessentially executive function. ${ }^{130}$

There is, however, a complete answer to the inquiry that Justice Scalia puts merely as a rhetorical question. Indeed, the majority's failure to utter this answer more clearly is surprising. It is possible, quite simply in the instance of independent counsel, to interpret "executive power" according to the founders' conventional understandings of what that power encompassed. The historical case is compelling that late-eighteenth-century political and legal thinkers did not understand criminal prosecution as an inherently executive function. ${ }^{131}$ Even if courts and Congress could not conduct prosecution directly, it is possible to treat "executive power" as not including criminal prosecution as an inherent element. If the President is deemed constitutionally entitled to plenary policy control only over those functions that were inherently executive from the founders' point of view, then Congress would have discretion to vest prosecutorial functions in non-legislative, non-judicial officers who would also be substantially independent of the President. In this way, the majority opinion could be defended on squarely formalist grounds.

The legislative case for the Ethics in Government Act had originally been made, however, and the Carter Administration's support had been expressed, in terms perhaps more consistent with what I have called a checked separationist or checks and balances defense of the Act. Such a defense need not deny that the greater decisionmaking autonomy of independent counsel, as compared to other federal prosecutors, might intrude upon executive decisionmaking. It would pose the question, however, whether any such intrusion would be overbalanced by a weightier contribution that the statute makes to the protection of some other constitutionally authorized purpose. In President Carter's words, the purpose of the Act was to “eliminate all appearance of high-level interference in [politically] sensitive investigations and prosecutions." 132 And, in this respect, it is notable that the Act is limited in its applicability to those high-level political officials and associates of the President as to whom the executive's conflict of interest in conducting a prosecution would

130. Id. at 706 (Scalia, J., dissenting).

131. Gwyn, Federal Cours, supra note 42, at 493-502; Shane, supra note 42, at 603-06.

132. Ethics in Government, supra note 116, at 649. Interestingly, President Carter appears personally to have regarded public confidence in apolitical law enforcement as a weightier concern than presidential control over prosecution generally. He initially went so far as to request that the Justice Department prepare legislation providing a definite term appointment for the Attorney General, subject to removal only for malfeasance. The Justice Department, presumably with White House consent, actually published an Attorney General letter declining to do so on the ground that such an Act would probably be held unconstitutional. 1 Op. Off. Legal Counsel 75 (1977). 
be most conspicuous. It is as to this category of persons that the public could justly be most dubious of the rigor of presidential law enforcement.

Conversely, even within this realm, the Act stops far short of eliminating executive discretion. Whether to initiate a preliminary investigation or to request the appointment of independent counsel were decisions left by the statute to the judicially nonreviewable discretion of the Attorney General, ${ }^{133}$ an executive official who is typically a close personal ally of the President. The Act required independent counsel to abide by Justice Department policy unless it was not "possible" to do so. ${ }^{134}$ Finally, the Attorney General retained power to dismiss independent counsel for good cause. ${ }^{135}$ These accommodations of executive discretion, even for investigations within the purview of the Act, helped guarantee that the Act would not "prevent the Executive Branch from accomplishing its constitutionally assigned functions. ${ }^{136}$ In short, even if the Act represented a formal breach of the separation of powers, it would be constitutional because of what it accomplished for the preservation of executive branch integrity, an objective within Congress's power to pursue, and because Congress carefully tailored its "breach" of separation to achieve the Act's limited purpose.

A categorical separationist would quite likely object that the balancing judgment on which this analysis depends is too subjective. Who is to say what purposes justify a breach in formal separation? Who is to say how much good need be done in the name of those purposes to justify the breach? The checked separationist's answers to both questions, however, are straightforward, and they rescue a deciding judge from the charge and burden of unbridled subjectivity in constitutional interpretation.

First, the purposes that justify a breach in formal separation must be embodied in the Constitution itself. Note, for example, that the Constitution divides governmental powers both to permit the checking and balancing of each branch by the others, and also to insure that the mission assigned to each branch is most likely to be implemented effectively. ${ }^{137}$ Key protections for Congress's legislative authority are located not only among its Article I powers of self-protection, but also in the Article II obligation that the President take care that the laws be faithfully executed. ${ }^{138}$ This language descends to us

133. The Act expressly makes the affirmative decision to seek independent counsel nonreviewable. 28 U.S.C. \$ 592(f) (1988). Courts have inferred that the decision whether to trigger a preliminary investigation and the decision whether to apply for independent counsel are likewise not reviewable. Banzhaf v. Smith, 737 F.2d 1167 (D.C. Cir. 1984) (en banc); Dellums v. Smith, 797 F.2d 817 (9th Cir. 1986).

134. 28 U.S.C. $\$ 594(f)(1988)$.

135. 28 U.S.C. \& 596(a)(1) (1988).

136. Morrison v. Olson, 487 U.S. 654, 695 (1989).

137. Youngstown Sheet \& Tube Co. v. Sawyer, 343 U.S. 579, 635 (1952) (Jackson, J., concurring); Louis Fisher, The Efficiency Side of Separated Powers, 5 J. AM. STUD. 113 (1971).

138. U.S. CoNST. art. II, § 3 . 
from the English Bill of Rights, via the Virginia Constitution, and was intended to forbid the executive's suspension of statutes. ${ }^{139}$ The foreseeable impact of the conflicts of interest targeted by the Ethics in Government Act is precisely the de facto suspension of the criminal law for top officials of the executive branch. The effect of the Ethics in Government Act, seen in this light, is to increase the likelihood that Article II's mechanism for protecting Congress's lawmaking power will remain meaningful in instances of suspected executive lawlessness. To protect the separation of powers, the President is foreclosed from suspending statutes to protect himself politically. Thus, the Act is wholly consistent with a constitutionally authorized purpose.

Second, it is primarily for Congress to determine whether technical breaches of the separation of powers are justified by their positive effects in implementing legitimate legislative purposes. Courts, in turn, may review such congressional judgments for rationality. Congress has express power to "make all laws which shall be necessary and proper for carrying into execution . . . all . . powers vested by the Constitution in the government of the United States, or in any department or officer thereof. ${ }^{n 140}$ Thus, even if criminal prosecution were an inherently executive function, Congress would have authority to determine whether a measure is necessary and proper for carrying that function into execution. For a court "to inquire into the degree of its necessity, would be to pass the line which circumscribes the judicial department, and to tread on legislative ground."141 Rethinking the independent counsel dispute in this light, upholding the Ethics in Government Act hardly requires recourse either to unconventional ways of thinking about the Constitution or unconstrained judicial subjectivity that confuses the judge's personal assessment of the Act's policy wisdom with a principled judgment as to its validity.

\section{B. Iran-Contra and the Rule of Law}

But even if abstract legal argument were insufficiently persuasive to convince people of the necessity for independent counsel-or the preferability, in general, for the checks and balances philosophy that the mechanism implements-the Iran-Contra events should suffice. The political context within which those events occurred displayed both categorical separationist and checks and balances elements at work. As already noted, Presidents have been largely successful in conducting foreign policy within categorical separationist assumptions. On the other hand, Congress enjoys express control over both appropria-

139. Shane, supra note 42, at 613; Charles Tiefer, The Constitutionality of Independent Officers as Checks on Executive Abuses of Executive Power, 63 B.U. L. REv. 59, 90 (1983).

140. U.S. ConsT. art. I, $\S 8$, cl. 18.

141. McCulloch v. Maryland, 17 U.S. (4 Wheat.) 316, 423 (1819). 
tions $^{142}$ and the regulation of foreign trade. ${ }^{143}$ Congress had exercised its appropriations powers to bar Contra aid and had legislated a series of restrictions regarding U.S. arms sales, including the resale of U.S. arms by third parties. Moreover, Congress had enacted a series of formal requirements for the conduct of covert operations, to assure presidential accountability and timely congressional notification.

Not surprisingly, supporters and critics of the Iran-Contra initiatives have offered different assessments not only of the degree of legal laxity involved, but also of the relationship between the appearance of lawlessness and the influence on the relevant officials' behavior of the competing elements of categorical and checked separationism. Both Oliver North and his congressional defenders essentially suggested that any unlawful aspects of Iran-Contra flowed from Congress's failure to recognize the executive's plenary constitutional authority in foreign policy. ${ }^{144}$ According to this "the-devil-made-us-doit" scenario, Congress had no right to interfere with President Reagan's foreign policy determination that Contra support was in the interest of the United States. Had Congress supported or at least deferred to the Reagan policy, the President could have pursued Contra aid without violating any statute and the NSC would not have been tempted to support covert arms sales as a source of financial support for the Contras.

Critics, in contrast, have asserted both the legality of Congress's initiatives in foreign affairs and the dangers posed to democracy of resisting those initiatives through covert and deceitful means. ${ }^{145}$ The Reagan Administration was never able to persuade a majority of Americans that financial aid to the Contras was significantly in the interest of the United States ${ }^{146}$-and never

142. U.S. CoNST. art. I, §§ 7, 8, cl. 1 .

143. U.S. CONST. art. I, $\$ 8$, cl. 3 .

144. Iran-Contra Investigation: Joint Hearings Before the Senate Select Comm. on Secret Military Assistance to Iran and the Nicaraguan Opposition and the House Select Comm. to Investigate Covert Arms Transactions with Iran, 100th Cong., 1st Sess., Pt. 1, at 190-191 (1987) [hereinafter North Hearings] (testimony of Oliver L. North); IRAN-CONTRA REPORT, supra note 9, at 663 (additional views of Rep. Broomfield), 666 (supplemental views of Sen. Hatch).

145. See generally Louis Henkin, Constitutionalism, Democracy, and Foreign AfFairs 40 (1990); KoH, supra note 8; Louis Fisher, How to Avoid Iran-Contras, 76 CAL. L. REV. 939 (1988) (reviewing Edmund S. Muskie ET AL., The President, Congress, AND Foreign Policy (1986)); Theodore Draper, The Constitution in Danger, N.Y. REV. OF BoOKs, Mar. 1, 1990, at 41.

146. A search of the Westlaw Poll Database for the terms "aid" and "Contra" revealed that, in March 1986, a Gordon S. Black poll done for U.S.A. Today asked whether respondents "favor or oppose military aid to the Contras fighting the Sandinista government in Nicaragua?" The response was $37 \%$ in favor, $44 \%$ opposed, and 19\% responding "don't know" or refusing to answer. In September 1986, 47\% of respondents told a Yankelovich, Clancy, Shulman survey that they would be less likely to vote for a candidate who favored giving U.S. military aid to the Contras. (Twenty-five percent would have been more likely to vote for such a candidate.) In April 1985, the number of respondents in a Los Angeles Times poll favoring "no aid" to the Contras slightly outnumbered those favoring "humanitarian aid" (39\% to $37 \%$ ) and greatly outnumbered those favoring aid in the form of weapons (39\% to $12 \%)$. 
tried to persuade anyone that trading arms for hostages was sound policy. ${ }^{147}$ Under this view, the Boland Amendments were proper "checks" designed to align U.S. foreign policy with the views of the electorate, just as the relevant arms control laws fell squarely within Congress's power to regulate foreign trade. Thus, far from promoting illegality, Congress was simply doing its job. Only the arrogance of an executive that overestimated its inherent and exclusive authorities could have fostered an atmosphere in which deceit and covert adventurism were considered proper governance activity.

Of these two competing assessments of executive behavior during IranContra, the latter narrative seems plainly the more convincing. Of course, had Congress enacted fewer laws regulating the executive, it is less likely that Iran initiatives, Contra initiatives, or any other initiatives would have violated the law. But this is obviously question-begging. It is hardly a strong argument for the consistency of categorical separationism with the rule of law that, under categorical separationism, there would be less law to rule.

Moreover, the record makes clear that the impetus for the most troubling aspects of the Iran-Contra affair-namely, the very conception of the arms-forhostages deal and the repeated deceit of Congress-lay not in the executive's constitutional convictions as to the scope of its authority, but rather in its apprehension that its policies would not enjoy support outside the Administration. Congress had not categorically outlawed the sort of arms deal that President Reagan authorized. The Administration evaded the applicable statutory notice requirements because it was not prepared to defend the merits of these particular sales, ${ }^{148}$ even under the highly protective rules that the intelligence committees have devised for the sharing of sensitive information. ${ }^{149}$

147. Indeed, President Reagan insisted this was never his policy. See President's Interview with Television Network Anchormen, 23 WEEKLY COMP. PRES. Doc. 1424, 1430 (Dec. 3, 1987) (“Never at any time did we view this as trading weapons for hostages, because we weren't doing anything for the kidnappers."); President's News Conference, 22 WEEKLY COMP. PRES. Doc. 1583 (Nov. 19, 1986) ("To eliminate the widespread but mistaken perception that we have been exchanging arms for hostages, I have directed that no further sales of arms of any kind be sent to Iran."); Excerpts From Reagan's Testimony on the Iran-Contra Affair, N.Y. TIMES, Feb. 23, 1990, at A18 ("They didn't say it was trading for hostages "cause it wasn't.").

148. Both Secretary of State George P. Schultz and Secretary of Defense Caspar Weinberger had opposed the sales and tried to stop them. Theodore Draper, The Iran-Contra Secrets, N.Y. REV. OF Books, May 27, 1993, at 43, 43-46.

149. The rules of each House provide:

A. Committee employees must agree in writing to abide by committee rules and must receive an appropriate security clearance before receiving access to classified information. Standing Order of the Senate on the Select Committee on Intelligence [hereinafter Senate Intelligence Committee Order], \& 6, reprinted in SENATE COMM. ON Rules AND ADMINISTRation, SENATE MaNuAL, S. Doc. No. 1, 100th Cong., Ist Sess. 141 (1988) [hereinafter SENATE MANUAL]; House of Representatives Rule XLVIII [hereinafter House Intelligence Committee Rule], § 5, reprinted in WILLIAM H. BROWN, CONSTITUTION, JEFFERSON'S MANUAL, AND RULES OF THE HOUSE OF REPRESENTATIVES, H.R. DOC. 248, 100th Cong., 2d Sess. 756 (1988) [hereinafter JEFFERSON's MANUAL];

B. members of the committees are forbidden to disclose information individually if the rules provide that such information may be released only pursuant to committee vote, Senate Intelligence Committee Order, \& 8(a), reprinted in SENATE MANUAL, at 142; House Intelligence Committee Rule, § 7(a), reprinted 
Likewise, the Administration had internally taken the position that independent financing for the Contras was consistent with the Boland Amendments. ${ }^{150}$ The Administration could have taken that position in confidential discussions with Congress and avoided the dangerously unaccountable backchannel operation that North designed. Alternatively, the Administration could have invoked executive privilege to shield information about its efforts. Yet, to do either would again have risked hostile congressional inquiry-and would have made it impossible for the Administration to claim publicly that the Boland Amendments were seriously compromising the Contras' capacity to find financing. The NSC strategy was the consequence, in other words, not of congressional encroachment into executive authority, but rather of a probably sound political determination that neither half of the Iran-Contra package could be persuasively "sold" to the relevant committees as good policy. The transmutation of political considerations into exaggerated self-assurance within the executive as to its constitutional prerogatives is just the sort of corruption that checks and balances are presumably intended to curb.

The critiques of independent counsel do highlight one inevitable truth of government: even in a system of checks and balances, trust must be reposed in the exercise of discretion by someone. With regard to criminal prosecutions, using independent counsel to secure a dispassionate review of executive branch wrongdoing shifts discretion from the Justice Department to a different office. Thus, discretion as an element of the system does not disappear; it just changes location. Further, where there is discretion, there may be abuse. But whether the performance of Counsel Lawrence Walsh reveals real dangers in the use of independent counsel to vindicate the rule of law requires an assessment deeper than this truism. We must first consider whether the accusations of Walsh's misconduct are well-founded. Then, whatever the answer, we must consider whether the discretion vested in any independent counsel poses greater dangers to the rule of law than either (a) foregoing all prosecution of corruption akin to Iran-Contra or (b) reposing all such prosecutions in the Justice Department.

Unless one accepts the implicit premise that Iran-Contra was not a serious enough episode to investigate, the criticisms of Walsh's investigation as too long and too expensive seem blatantly overstated. The Iran-Contra affair

\footnotetext{
in JEFFERSON's MANUAL, at 757;

C. the President may object to a committee vote to disclose properly classified information submitted to it by the executive branch, in which case the information may be disclosed only pursuant to a vote of the entire House, Senate Inteiligence Committee Order, § 8(b), reprinted in SENATE MANUAL, at 142-43; House Intelligence Committee Rule, $\$ 7(\mathrm{~b})$, reprinted in JEFFERSON's MANUAL, at 757-59; and

D. the committees may regulate and must record the sharing of information made available to them with other committees or with any Member of Congress not on the committees, Senate Intelligence Committee Order, $\$ 8(\mathrm{c})$, reprinted in SENATE MANUAL, at 144; House Intelligence Committee Rule, $\S$ 7(c), reprinted in JEFFERSON's MANUAL, at 760.
}

150. See generally Sciaroni, supra note 15. 
involved an extensive international cast of characters and a highly intricate series of transactions. ${ }^{151}$ Perhaps most to the point, the Bush Administration fought hard and at great length to prevent Walsh's acquisition of a good deal of the material he sought to support his investigation. ${ }^{152}$ When Oliver North and Joseph Fernandez insisted that disclosure of a substantial amount of classified material was necessary to their respective defenses, the Bush Justice Department successfully supported the CIA and NSC in opposing disclosure under the Classified Information Procedures Act, ${ }^{153}$ thus thwarting much of Walsh's case. ${ }^{154} \mathrm{GAO}$ audits of the independent counsel's office have yet to find any "irregularities" that are not routine government practice and treated as such by the Government Services Administration. ${ }^{155}$

As for results, the record is a complex one. Walsh ultimately charged fourteen people with offenses related to the Iran-Contra affair. Seven pleaded guilty to various charges: Elliott Abrams, ${ }^{156}$ Carl Channell, ${ }^{157}$ Alan Fiers, ${ }^{158}$ Albert Hakim, ${ }^{159}$ Robert McFarlane, ${ }^{160}$ Richard Miller, ${ }^{161}$ and

151. Independent Counsel Reauthorization Act of 1992, supra note 121, at 71-83 (statement of Samuel Dash and Irvin B. Nathan on behalf of the ABA).

152. This will be most fully documented in the final report of the independent counsel. At the time of this writing, a federal appellate court panel had announced that it would make the report public, but had set no date for public release. David Johnston, Panel to Release Concluding Report in Arms Case, N.Y. TIMES, Dec. 4, 1993, at 1 . (1988)).

153. Pub. L. No. 96-456, 94 Stat. 2025 (1975) (codified as amended at 18 U.S.C. app. §§ 1-15

154. United States v. North, 713 F. Supp. 1441 (D.D.C. 1989); United States v. Fernandez, 913 F.2d 148 (4th Cir. 1989); Ronald K. Noble, The Independent Counsel Versus the Attomey General in $a$ Classified Information Procedures Act-Independent Counsel Statute Case, 33 B.C. L. REV. 539, 556-63 (1992).

155. See 139 Cong. Rec. S3285 (daily ed. Mar. 19, 1993) (statement of Sen. Levin). For an example of the attack to which Senator Levin was responding, see 139 CONG. REC. S4392 (daily ed. Apr. 2, 1993) (statement of Sen. Wallop).

156. Abrams, a former Assistant Secretary of State, pleaded guilty on October 7, 1991, to two misdemeanor counts of withholding information from Congress about secret Government efforts to aid the Nicaraguan rebels: “Prosecutors said that he knew that Oliver L. North, then a National Security Council aide, had been in contact with people supplying the contra rebels and encouraged them to continue to aid the rebels despite a Congressional ban on such aid. He was sentenced Nov. 15, 1991, to two years' probation and 100 hours of community service." David Johnston, The Pardons: Bush Pardons 6 in Iran Affair, Aborting a Weinberger Trial; Prosecutor Assails "Cover-up," N.Y. TIMES, Dec. 25, 1992, at A1.

157. Channell, a private businessman, allegedly helped North "raise money from private donors for the contras. [He] pleaded guilty to a charge of conspiring to defraud the Government by soliciting taxdeductible donations for non-deductible purposes, and [was] sentenced to probation." Id.

158. Fiers, the "former head of the C.I.A.'s Central American Task Force . . . pleaded guilty on July 9, 1991, to two misdemeanor charges of withholding information from Congress about diverting money form Iranian arms sales to the Nicaraguan contras. He was sentenced Jan. 31, 1992, to one year's probation and 100 hours of community service." Id.

159. Hakim is an "Iranian-born businessman who created a company to funnel arms and money to the contras. He pleaded guilty on Nov. 21, 1989 to a misdemeanor charge of providing an illegal gratuity to Mr. North by paying for a security fence at Mr. North's home. He was sentenced on Jan. 24, 1990, to two years' probation." Id.

160. McFarlane, President Reagan's National Security Advisor, pleaded guilty on March 11, 1988, to four misdemeanor charges of withholding information from Congress. On March 3, 1989, he was sentenced to two years' probation and 200 hours of community service and fined $\$ 20,000$. Id. 
Richard Secord. ${ }^{162}$ Juries convicted another four: Thomas Clines, ${ }^{163}$ Clair George, ${ }^{164}$ Oliver North, ${ }^{165}$ and John Poindexter. ${ }^{166}$ Cases against Joseph Fernandez, ${ }^{167}$ Duane Clarridge, ${ }^{168}$ and Casper Weinberger ${ }^{169}$ never went to trial-Fernandez's because of Walsh's inability to secure the release of necessary classified information; Clarridge's and Weinberger's because of Presidential pardons.

What further complicates the record, of course, is not only the pardoning of five of these defendants, but the D.C. Circuit's decisions either mandating or making inevitable the reversal of any convictions in the most important prosecutions, those of North and Poindexter. ${ }^{170}$ In North, however, the court

161. Miller, another businessman who helped North raise money from private donors for the contras, pleaded guilty to a charge of conspiring to defraud the Government by soliciting tax-deductible donations for non-deductible purposes, and was sentenced to probation. Id.

162. Secord, a retired Air Force major general, "played a crucial role in the secret arms shipments to Iran and support for the Nicaraguan rebels. He pleaded guilty on Nov. 8, 1989, to lying to Congressional investigators. He was sentenced on Jan. 24, 1990, to two years' probation." Id. He had originally been charged with giving an unlawful gratuity to a government official, perjury, obstruction of Congress, and giving false statements in connection with the Iran-Contra initiative. United States v. Secord, 726 F. Supp. 845,846 (D.D.C. 1989).

163. "The former C.I.A. agent was a business partner of Mr. Secord and Mr. Hakim in supplying arms to Iran. He was convicted Sept. 18, 1990, on four felony counts involving the underreporting of his earnings to the Internal Revenue Service in 1986 and 1987 and falsely telling the Government that he had no foreign bank accounts. On Dec. 13, 1990, he was sentenced to 16 months in prison and fined $\$ 40,000$. A Federal appeals panel upheld the convictions on Feb. 27, 1992. He began serving his jail sentence on May 25, the only defendant in the scandal to go to prison." Johnston, supra note 156 , at $\mathrm{A1}$.

164. George was formerly deputy chief of operations for the CIA. "The highest-ranking former C.I.A. official charged in the scandal, he was indicted Sept. 6,1991, on 10 counts of perjury, false statements and obstructing Congressional and Federal investigators. He pleaded not guilty on Sept. 12, 1991. Three obstruction-of-justice charges were dismissed by a Federal judge [on] May 18 [, 1991]; two new obstructionof-justice charges were filed two days later. A first trial ended in a mistrial in August, when the jury failed to reach a unanimous verdict. After a second trial, he was found guilty on Dec. 9 of two counts of lying to Congress, and faced sentencing in February of up to five years in prison and a $\$ 250,000$ fine." Id.

165. "The former Marine lieutenant colonel was a staff member of the National Security Council. [He] was convicted on May 4, 1989, on three felony counts for his role in the Iran-Contra affair: aiding and abetting obstruction of Congress, destroying security council documents and accepting an illegal gift. He was acquitted on nine counts. He was sentenced July 5, 1989, to two years' probation and 1,200 hours of community service and fined $\$ 150,000$." Id.

166. Poindexter succeeded Robert McFarlane as President Reagan's National Security Advisor from December 1985 to November 1986. He "was convicted on April 7, 1990, on five counts involving charges that he obstructed, conspired to obstruct and made false statements to Congress. He was sentenced June 11,1990 to six months in prison." ld.

167. The former CIA station chief in Costa Rica was charged with making false statements to the CIA Inspector General and to the Tower Commission. U.S. v. Fernandez, 913 F.2d 148, 150 (4th Cir. 1990).

168. “The Central Intelligence Agency's former chief of European operations was indicted Nov. 26, 1991 , on 10 counts of perjury and making false statements stemming from a secret missile shipment to Iran in November 1985. He pleaded not guilty on Dec. 6, 1991. On Dec. 10, a Federal judge ordered prosecutors to drop two charges from the indictment. No trial date had been set." Johnston, supra note 156 , at $\mathrm{A} 1$.

169. “The former Defense Secretary ... was indicted in June [1992] on five felony charges, including accusations that he had lied to Congress and concealed more than 1,700 pages of notes from a personal diary recording his discussions with other officials about arms sales to Iran. He was indicted again on Oct. 30 on a charge of making a false statement to Congress. The indictment was brought to replace a similar charge dismissed in September by a Federal district judge." Id.

170. United States v. North, 910 F.2d 843 (D.C. Cir. 1990); United States v. North, 920 F.2d 940 (D.C. Cir. 1990); United States v. Poindexter, 951 F.2d 369 (D.C. Cir. 1991). 
made new and more stringent law on the steps necessary to protect criminal defendants from the use at trial of immunized testimony before Congress. ${ }^{171}$ The Poindexter decision unexpectedly narrowed the reach of the obstruction of justice statute under which Poindexter was prosecuted. ${ }^{172}$ It is difficult to fault independent counsel for not anticipating these rulings.

Aside from the merits of the particular criticisms levied at Lawrence Walsh, the case against independent counsel is weak for a deeper reason. Independent counsels, even if politically independent and vested with broad prosecutorial discretion, hardly operate in the insulated atmosphere that the executive typically seeks to create for itself in foreign affairs. The focused and high-profile nature of their task assures public and congressional scrutiny far more intense than ordinary prosecutors receive regarding their day-to-day business. Independent counsel may overmatch their targets in legal resourcesa complaint of virtually every federal criminal defendant-but, like U.S. attorneys, they can do no more than invoke the assistance of the judicial process to effect their prosecutorial goals. They cannot covertly and without accountability circumvent the law to deny individual rights. There is thus simply no comparison between the magnitude of risk posed to government by roving independent counsel and the risk posed by unregulated covert executive action in the fields of foreign and intelligence policy.

Moreover, the alternatives to independent counsel in the Iran-Contra affair would not have been satisfactory. Foregoing all prosecution of the people involved would have left an historical record even muddier than we now have. ${ }^{173}$ There is an obvious tension between theoretical support for plenary presidential authority regarding foreign affairs on grounds of accountability and the efforts of Presidents who largely possess such authority to shield their exercise of power from public exposure. The Reagan Administration strove mightily to avoid tying the President to the Contra aid effort, ${ }^{174}$ and the

171. United States v. North, 910 F.2d at 924 (Wald, J., dissenting); United States v. North, 920 F.2d at 951-54 (Wald, J., dissenting).

172. United States v. Poindexter, 951 F.2d at 388 (D.C. Cir. 1991) (Mikva, J., dissenting); Ralph Drury Martin, Poindexter and the Truth About Lying, LEgAL TmES, Dec. 2, 1991, at 25.

173. For example, although author Theodore Draper was able to write an historical account of the Iran-Contra affair based on documents released during the congressional hearings, THEODORE DRAPER, A VERY THIN LINE: THE IRAN-CONTRA AFFAIRS (1991), the apparent knowledge and role of then-Vice President Bush were significantly amplified by diaries he released only under prodding by the independent counsel. Theodore Draper, Iran-Contra: The Mystery Solved, N.Y. REV. OF BooKS, June 10, 1993, at 53, 54-59.

174. President's Interview with Television Network Anchormen, supra note 147, at 1430 ("I did not know about the diversion of funds."); Excerpts From Reagan's Testimony on the Iran-Contra Affair, supra note 147 , at $A 18$ ("all I know is that some sum of money over and above the $\$ 12.2$ million purchase price appeared in a Swiss back [sic] account in which it was said that account had been used on another occasions [sic] to provide help to the contras." "I still with all of the investigations that have been made, I still have never been given one iota of evidence as to who collected the price, who delivered the final delivery of the weapons, or what was-whether there was never more money in that Swiss account that had been diverted someplace else." "I had no knowledge then or now that there had been a diversion, and I never used the term."); Remarks of President Reagan at a Bill Signing Ceremony, Los Angeles, Califormia. FED. 
President repeatedly denied that the sale of arms to Iran represented the policy of negotiating with terrorists that it obviously embodied. ${ }^{175}$ Far from producing coherent, accountable policymaking, the Iran-Contra project was a diffuse and systematic evasion of responsibility. Prosecution has been central to establishing where blame lay. The other alternative, reposing all prosecutorial discretion in the Justice Department, would not have satisfied the public expectations of a nonpartisan probe. Had a Bush Attorney General declared matters closed without seeking convictions, it is doubtful that the public would have confidently embraced the outcome. ${ }^{176}$

A "rule of law" assessment of the Iran-Contra affair must take account of what presumably will be the near-final chapter: President Bush's pardon of Caspar Weinberger, Elliott Abrams, Duane Clarridge, Alan Fiers, Clair George, and Robert McFarlane. ${ }^{177}$ President Bush explained these pardons on five grounds. He asserted that (a) the named individuals were motivated by patriotism, not by hope of private gain, in any alleged malfeasance; ${ }^{178}$ (b) their prosecutions were tantamount to the "criminalization of policy differences"; ${ }^{179}$ (c) pardons are often used to put national political traumas to

NEwS SERV., Oct. 31, 1988 (denying knowledge of excess funds from missile sales) ("I am still asking, after ten months of a Congressional investigation, I still don't know who delivered the weapons and .. . where the money came from.").

175. See President's Interview with Television Network Anchormen, supra note 147, at 1430 ("token shipment of arms" sent only after contacts in Iran "made it pretty plain they didn't support terrorism"); Statement and a Questions and Answers Session with Reporters, 23 WEEKLY COMP. PRES. DOC. 529, 531 , (May 15, 1987) ("We were not doing business with [Khomeini] at all." Those dealing with the United States had said "they were opposed also to the support of terrorism."); Remarks of President Reagan at a Bill Signing Ceremony, supra note 174, at 1430 (denying dealings with terrorists or with Iran, but rather "with people who were looking forward to a day when there could be a decent government in Iran").

176. William Barr, who succeeded Richard Thornburgh as Attorney General, refused to seek independent counsel in connection with two substantial sets of accusations against the Bush Administration. One matter, "Iraqgate," involved allegations that Administration officials sought to obstruct a Justice Department investigation into allegations that Iraq used U.S.-guaranteed agricultural loans to purchase sensitive military technology. Carroll J. Doherty, Boren Leads Renewed Request for Iraq-BNL Investigation, 50 CONG. Q. WKLY. REP. 3257 (1992). The second matter, the so-called "Inslaw Scandal," involved the government's alleged theft from Inslaw, Inc., a software developer, of a litigation tracking program intended to be sold covertly to other countries. Elliott Richardson, A High-Tech Watergate, N.Y. TIMES, Oct. 21, 1991, at A15. In each case, Barr instead appointed a retired judge to serve as Barr's special investigator into the matter. Each investigator's report, concluding that no wrongdoing occurred, has failed to silence those who made the original accusations. Joel Bleifuss, Inslaw Breakers, IN THESE TIMES, Aug. 9, 1993, at 12-13; Tommy Denton, Wheels of Justice Crush the Truth, The PLAIN DEALER, Dec. 17, 1992, at 11B ("Screams of outrage are echoing across the land over the report from U.S. Attorney General William P. Barr's 'special' counsel, Frederick B. Lacey, who last week dutifully exonerated the Justice Department of any official mischief in the Iraqgate scandal."); Neil A. Lewis, Judge Scoffs at Defense of Bush on Iraq, N.Y. TIMES, Aug. 24, 1993, at A10.

177. Proclamation No. 6518, 28 WEEKLY COMP. PRES. Doc. 2382 (Dec. 23, 1992).

178. Id. at 2383 .

179. Id. It is more than a little revealing that the President's proclamation embraced Oliver North's characterization of Congress's Iran-Contra investigation: "It is mind-boggling to me that . . . some here have attempted to criminalize policy differences . . . . North Hearings, supra note 144, at 191. Since North's statement, "criminalization of policy differences" has become a recurrent right-wing sound-bite in discussions of the Iran-Contra Affair-a phenomenon both to be decried and to be blamed on liberals. See, e.g., Poindexter's Punishment, WALL ST. J., June 8, 1990, at A10 (asserting that imprisonment of Poindexter would align federal judiciary on side of congressional criminalizing of policy differences with 
rest ${ }^{180}$ (d) all those pardoned had been punished enough by the criminal process for any wrongdoing in which they might have been involved; ${ }^{181}$ and (e) Weinberger, at least, is so distinguished a public servant that his prior record alone argues for leniency. ${ }^{182}$

Yet, each of these arguments is tainted by the very cast of mind that nurtured the Iran-Contra affair in the first place. Consider, first, the President's stress on the defendants' patriotism. The obligations of public officethe fiduciary role of office holders ${ }^{183}$-fairly demand that public officials weigh the widest range of consequences in deciding the proper course of their own conduct. Their capacity to do harm compels it. To accept our officials' general character or overall intentions as the full measure of their moral responsibility in the discharge of their functions, however, would excuse them of any obligation to anticipate reasonably or assess plausibly the consequences of their acts. ${ }^{184}$ Especially because people in power rarely distrust their own motives, ${ }^{185}$ licensing our officials to treat their own sincerity as exculpatory without attention to consequences could operationally all but extinguish the possibility of rigorous administrative ethical standards in the executive bureaucracy.

As for the alleged "criminalization of political differences," no one-

executive branch); Terry Eastland, Consider Another Pardon Source, WASH. TMES, Nov. 13, 1992, at F1 (urging President-elect Clinton to pardon Weinberger, risking "the wrath of those Democrats in Congress (and they are legion) who believe in criminalizing policy differences."); Charles Krauthammer, A Referendum on Bush, Not a Revolution, THE PLAIN DEALER, Nov. 8, 1992, at 2C (criticizing Bush as "a consensus politician who long ago could have fired the Iran-contra prosecutor on grounds that the criminalization of policy differences had gone far enough-but who was unwilling to face the firestorm such decisiveness would have generated"); Paul Craig Roberts, Hounded from Office; Now Meese Falls to Left Wing's Criminalization of Differences, L.A. TMME, July 6, 1988, at B7 ("The criminalization of disagreement has already destroyed the quality of political life in Washington and is making the substantive discussion of issues irrelevant. The political left has a new way to win that is totally independent of policy facts and analysis."); George Will, Politicians, Nor Lawyers and Soldiers, WASH. PosT, July 10, 1987, at A23 ("liberalism's contribution to the current climate [is] the attempt to criminalize policy differences"). Intriguingly, a newsletter of the National Council of Teachers of English had "found testimony by Lt. Col. Oliver North at the Iran-Contra hearings a gold mine of doublespeak. It cited . . . his contention that the congressional investigation's purpose was to criminalize policy differences between co-equal branches of government." Fred M. Hechinger, Speak Nonobfuscatingly; Better Yet Clearly, CHIC. TRIB., Feb. 16, 1988, at Tempo, p. 3.

180. Proclamation No. 6518, supra note 177 , at 2382.

181. Id.

182. Id.

183. On the role of "fiduciary" as the central figure in properly delineating the ethical obligations of all public officials, see ABA Comm. on Gov't Standards, supra note 98, at 291-296.

184. DENNIS F. ThOMPSON, POlITICAL ETHICS AND PUBlic OfFICE 5-6 (1987) [hereinafter ThOMPson, Polttical ETHICs]; Dennis F. Thompson, The Possibility of Administrative Ethics, PUB. ADMIN. REV., Sept.-Oct. 1985, at 555, 560.

185. Currently, the government's presumption of its own integrity may impede accountability even in the operation of the ordinary judicial presumption that official action challenged in court was undertaken in good faith. See, e.g., Bridge v. U. S. Parole Comm'n, 981 F.2d 97, 106 (3d Cir. 1992) ("Government officials are presumed to act in good faith."). Unlike the pardons' invocation of good motives as a defense, however, the judicial presumption of good faith plays an important role in preserving the separation of powers and typically is not being deployed on behalf of the judge who makes the presumption. 
certainly not President Bush-has offered a serious argument that lying to Congress for the specific purposes of avoiding executive political accountability and, later, impeding the investigation of executive wrongdoing is anything other than a serious and morally culpable act. ${ }^{186}$ The former President's treatment of obviously plausible allegations of corrupt deception as acts of mere political vindictiveness by the prosecutor implicitly accepts the strategy of lying as itself a mere act of politics, and a justifiable act at that. ${ }^{187}$ It comes close to claiming that the President can do no wrong ${ }^{188}$ because what he does is political, and can be objected to only on political grounds.

Pardons can put national traumas to rest. The technique is especially effective when victors pardon the vanquished, or when those with standing to take offense offer forgiveness instead. ${ }^{189}$ The Lincoln/Johnson pardons of Confederate soldiers ${ }^{190}$ and the Truman/Carter pardons of those who violated selective service laws ${ }^{191}$ illustrate this point. Here, however, the President did not have identical standing to judge the defendants. His act was more akin to President Ford's pardon of Richard Nixon ${ }^{192}$ or President Reagan's pardon of rogue FBI agents, ${ }^{193}$ pardons with an unfortunately partisan cast. Worse yet, the Bush pardons violated the fundamental due process precept that people

186. Dennis Thompson argues that official deception in a democracy may be morally acceptable if necessary to accomplish an objective of which the people, if informed, would approve, and if (a) steps are taken to permit citizens the promptest possible review of the decisions being concealed, (b) the deception is of a kind that the public has generally endorsed as morally justifiable, without reference to the facts of the specific deception (such as the use of undercover narcotics investigators), or (c) the true circumstances hidden by the deception are shared in advance with a smaller group that effectively replicates the public debate that would likely occur if the deception were not necessary. THOMPSON, POLITICAL ETHICS, supra note 184, at 22-31. With respect to the instances of concealment or deception at issue in Iran-Contra, none of these conditions pertains.

187. Bush might have adopted a rationale for the pardons that would have been far less morally objectionable. At least for those officials charged with making unsworn false statements to Congress, he might have asserted that-in light of a lengthy history of widely acknowledged, but never prosecuted executive deceptions of Congress-the false statement statute did not fairly put the relevant officials on notice that their deceptive unsworn statements were, in fact, felonious. See generally Peter W. Morgan, The Undefined Crime of Lying to Congress: Ethics Reform and the Rule of Law, 86 Nw. U. L. REV. 177 (1992). This rationale might logically sustain a legal pardon, although it would not have amounted to the statement of moral and political approval for the deception of Congress that Bush apparently also wanted to provide.

188. Cf. Richard Nixon's famous statement: "When the President does it, that means it [is] not illegal." Nixon: A President Moy Violate the Law, U.S. NEWS \& WoRLD REP., May 30, 1977, at 65 (reporting on May 19, 1977 interview with David Frost).

189. Gary Wills, Bush's Shameless Finale; The Pardons Undermine Constitutional Intent, WasH. Post, Dec. 27, 1992, at C1. (1953).

190. JONATHAN T. DORRIS, PARDON AND AMNESTY UNDER LINCOLN AND JOHNSON 34-38, 108-115

191. Proclamation No. 4483, 42 FED. REg. 4391 (1977); Proclamation No. 2676, 10 Fed. Reg. 15,409 (1945).

192. Proclamation No. 4311, 3A C.F.R. 66 (1974)

193. Pardon for W. Mark Felt and Edward S. Miller, Statement By the President, 17 WeEKLY COMP. PRES. DoC. 437 (Apr. 15, 1981). 
should not judge their own cause. ${ }^{194}$ Presidents Ford and Reagan at least were not suspected of being unindicted co-conspirators in the acts being pardoned.

As for the defendants' distinguished pasts or the calculation that they suffered enough, we may ask what high-level wrongdoers would not say this of their equally lofty colleagues. It is never surprising to find that powerful officials regard themselves as self-sacrificing, are tempted to treat inconveniences imposed on them as punishment, and view themselves in comparison to perhaps wealthier friends as deserving of extra consideration in light of their preference for power over salary. ${ }^{195}$ Should these be factors relevant to a pardon at all, they should at least be weighed only once a record has been established that permits the public to make an assessment of the moral culpability of the defendants' acts. Waiting for a trial would serve the public interest in fact-finding. There is no evidence in President Bush's proclamation, however, that he reached his judgments based on a serious weighing of the moral culpability of the individuals involved.

The pardons, in my judgment, provide dramatic evidence of the dangers that categorical separationism poses for the rule of law. The President's pardon power is plenary; $;^{196}$ the Constitution's location of that plenary power in the

194. Independent Counsel Walsh apparently shares this opinion. Saul Friedman, Prosecutor Bashes Bush; Iran-Contra Won't Go Away, NewSDAY, Dec. 26, 1992, at 4. He is not alone. See, e.g., Carl Bernstein, Conspiracy Without End: The Lesson of Watergate; Politics: The Escalating Criminality of the Reagan-Bush Era Was an Effort to Undermine the Democratic Process and Hold Office at Any Price, L.A. TIMES, Jan. 10, 1993, at M1; William Schneider, Bush's Pardons Break All The Rules; Clemency: With Few Exceptions, a President Has Never Before Pardoned Former Colleagues-And Possible Co-conspirators, L.A. TIMES, Jan. 3, 1993, at M2.

195. Cf. "I have never profited from public service . . . I am not a crook," Richard Nixon, quoted in Bernstein, supra note 194.

196. A recent student note recommends that the President's pardon power be limited either to the postconviction stage or to certain crimes. The note does not provide a fully persuasive argument, however, that either limitation could be imposed without constitutional amendment. James N. Jorgenson, Note, Federal Executive Clemency Power: The President's Prerogative to Escape Accountability, 27 U. RICH. L. REV. 345 (1993).

The courts could conceivably determine, however, that Presidents are without power to pardon themselves. General Haig reportedly presented this option to Richard Nixon, who rejected it. Pardon of Richard M. Nixon, and Related Matters: Hearings Before the Subcomm. on Criminal Justice of the House Judiciary Comm., 93d Cong., 2d Sess. 94 (1974) (testimony of Pres. Ford), discussed in Daniel Schorr, Will Bush Pardon Himself?, N.Y. TIMES, Dec. 29, 1992, at A15. The "rule of law" arguments in favor of the President's amenability to criminal prosecution prior to impeachment, see Eric M. Freedman, The Law as King and the King as Law: Is a President Immune from Criminal Prosecution Before Impeachment?, 20 HASTINGS CONST. L. Q. 7 (1992), obviously counsel against any power of self-pardon. Indeed, a President's capacity to pardon himself would seem to violate flagrantly the cornerstone premise of due process and the separation of powers that people should not judge their own cause.

Interestingly, the chief objection to conferring the pardon power on the President was the fear of some critics that the President might use such authority to shield the President's confederates in treason. THE FEDERAlist, No. 74, at 448-449 (Alexander Hamilton) (Clinton Rossiter ed., 1961); W.H. HUMBERT, The Pardoning Power of THE PREsident 18 (1941). Although reasoning from snippets is problematic, it is worth noting the response of James Wilson to Edmund Randolph's unsuccessful proposal during the Philadelphia Convention to bar presidential pardons in treason cases. Wilson contended that a pardon power was needed even as to the crime of treason, and if the President "himself be a party to the guilt he can be impeached and prosecuted." 2 RECORDS OF THE FEDERAL CONVENTION OF 1787, at 626 (Max Farrand 
Presidents, Pardons, and Prosecutors

President is a formal aspect of separation of powers that even checked separationists must recognize. Yet, in his exercise of the pardon power, President Bush gave vent to the very sort of self-indulgent, even arrogant, self-assessment of the executive that represents an ethos of governance fundamentally at odds with the rule of law. Iran-Contra shows nothing in the executive's deployment of its discretionary powers to assuage one's unease about the consequences of categorical separationism for fidelity to law. Instead, the episode shows the importance of checks and balances to executive policymaking that is both coherent and accountable.

\section{CONCLUSION}

The public's faith in government, or lack of it, will probably always be rooted in the particular programs, policies, and problems of the day. But ideas also count. Our founders believed that the new Constitution deserved the allegiance of the citizenry in large part because of the ideas of governance that it embodied, including that of separation of powers.

"Separation of powers," however, is not self-defining. In the politics of the 1980s, as in earlier decades, our elected officials pursued contesting visions of separation of powers. One, the "categorical" version, would attribute to the President a significant range of inherent policymaking power, largely beyond Congress's or the courts' capacity to regulate. Another, the "checks and balances" version, would authorize a significant range of innovative measures, including independent counsels, to help assure executive fidelity to law, so long as the executive was not disabled from implementing its express constitutional responsibilities.

Advocates of both schools of thought customarily insist that theirs is the proper historical reading of the Constitution. But categorical separationists seek to fortify that position by emphasizing additionally the contribution categorical separation offers to values of coherence and accountability in government decisionmaking. The Iran-Contra affair, conducted within what the executive hoped would be an unregulated field of covert presidential discretion, hardly supports the case for coherence or accountability. But the affair also demonstrates a profound disadvantage of categorical separationist thinking: it does little to foster respect for law. By contrast, checks and balances can promote fidelity to law. It is chiefly the independent counsel, whose constitutionality is buttressed by the checks and balances model, who brought accountability to the Iran-Contra episode.

Indeed, the ultimate contribution of independent counsels to the public's

ed., 1937). 
faith in government may depend chiefly on their representation of the ideal of fidelity to law above ordinary politics. Government must exercise discretion in order to function effectively. But the checks and balances ethos underscores the degree to which each branch's discretion depends on the earned forbearance of the others, and the extent to which all government discretion depends on the consent of the governed. This is an appropriate cast of mind to frame all decisionmaking in a free nation under law. 